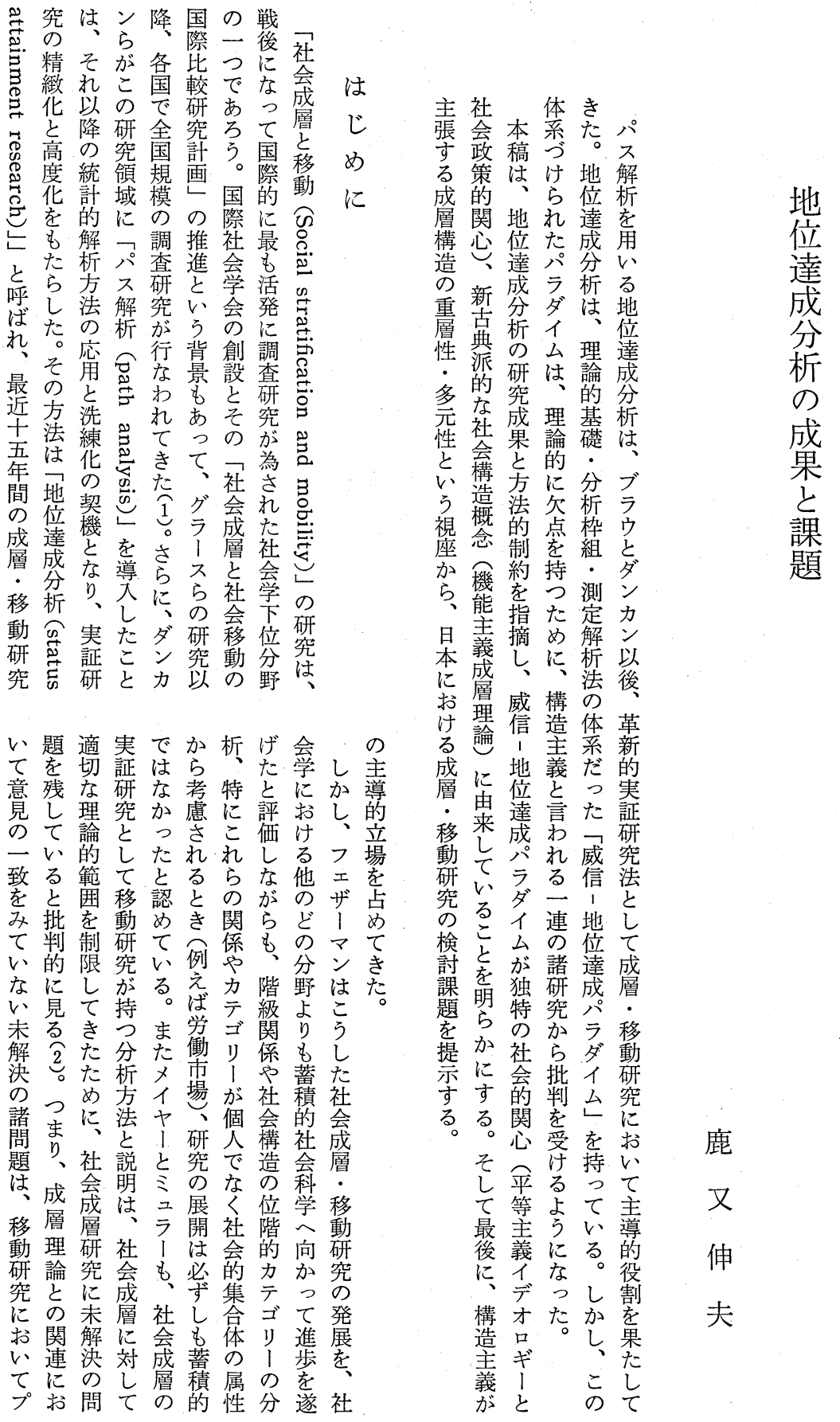




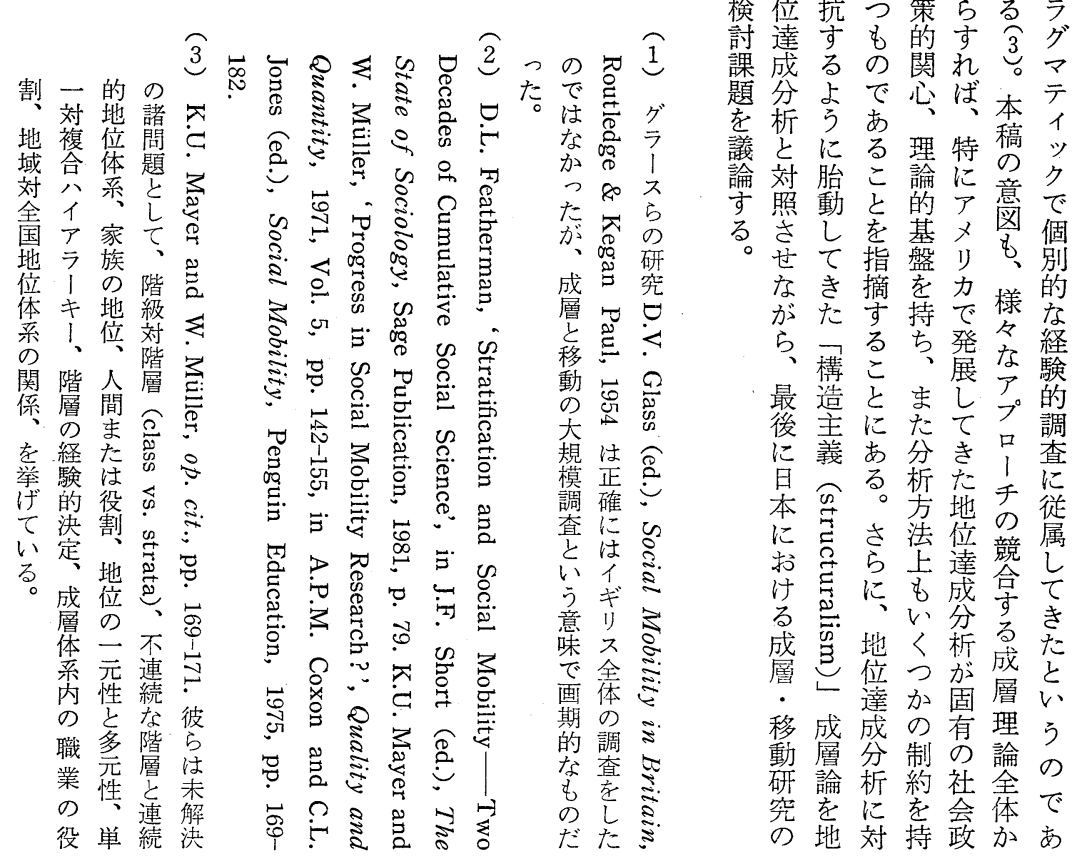

け客る析ア的地的数属数のて与研夕查れミ彼

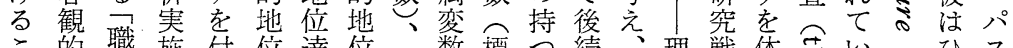

こ的職施付位達位職数標つ続、理戦体念いつひ

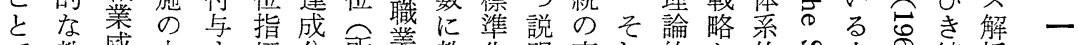

で教威方高標分所者教化明変れ的々的气人马続析

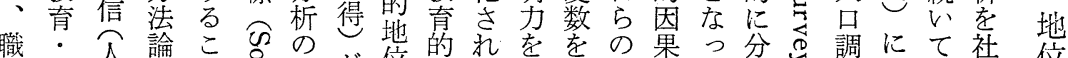

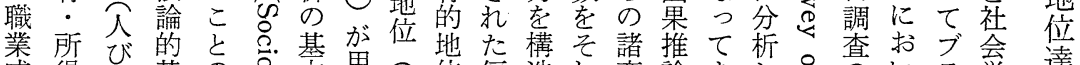

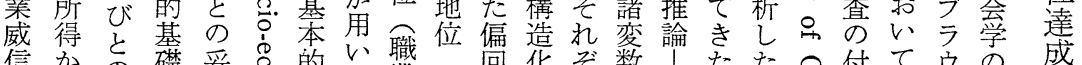

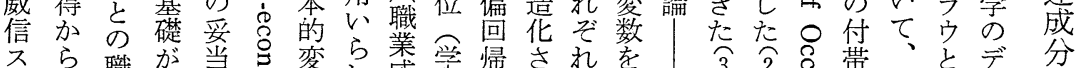

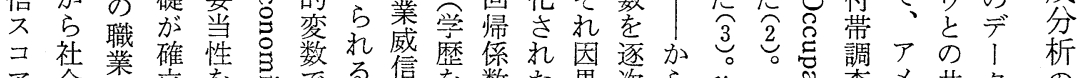

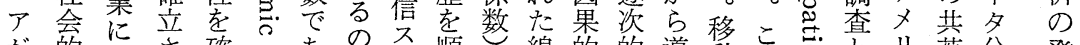

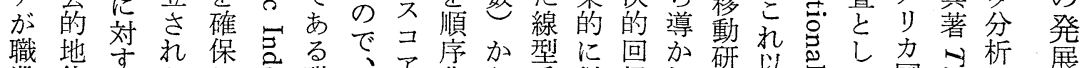

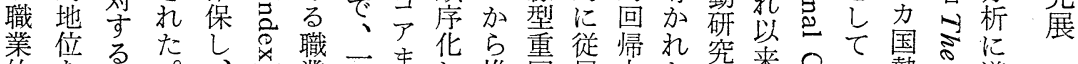

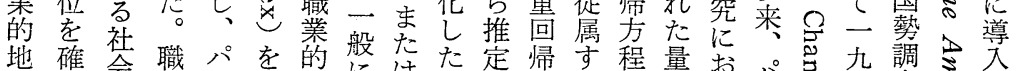

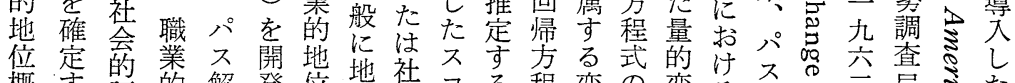

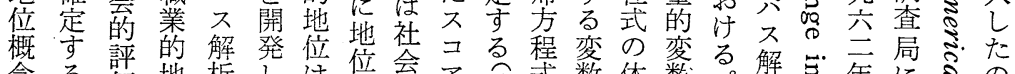

念る価地析し泣達会ア 経式数体数只解 $\Xi$ 年にミの

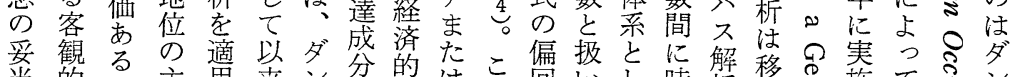

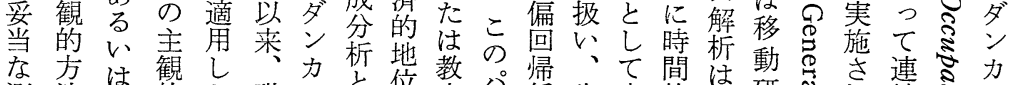

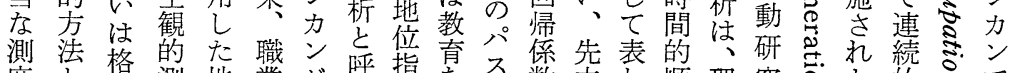

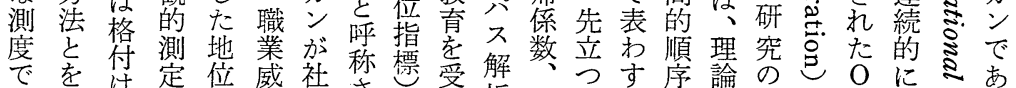

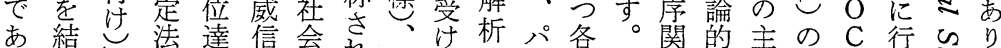

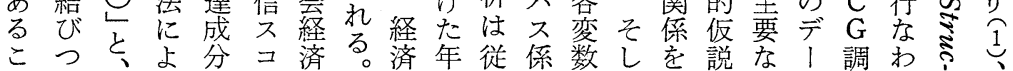


デ型 グしチつ動響のな的たのの度法ど技し流代析 間がブを

の析、究科り程間のっ位概念変発困らををし移社 ラ確

持: 加学、に接移た、念と量達難な導たし動会ウ証 続 ら $ら$ る的こお 的動。教】を解しない入めて移と: し 的、の加可こけ影過こ㕕|結析た社。すで扱と動多た 発状結を能 二る響程れの時合法多会パるあら年研ンの 展態合例性亏教索とら移間さと変事不こる分代究力で

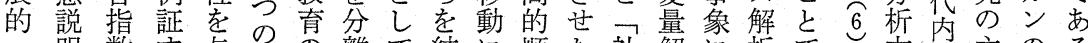
- 明数す守結の離て結に順た社解に析でこ方移主のる

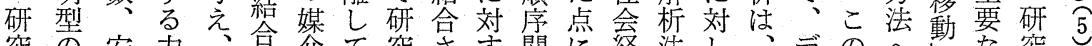
究の安力弇芥て究さ卞関に経法しはデのへ動な究 の分田強まは的言でせる係あ済のて自手とを研が

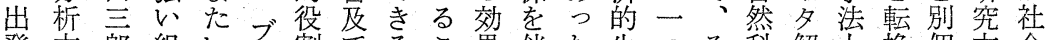
発方郎組いう割でるこ果伴た生つそ科解上換個方会

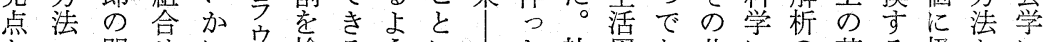
とへ開せにウ 検るうに社周あ共にの革る扱とに なの放だ社多証よによを世会期る変お精新とつなイ

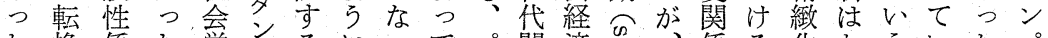
た換係た学ンるにってパ間済吕、係る化たら、いたパ

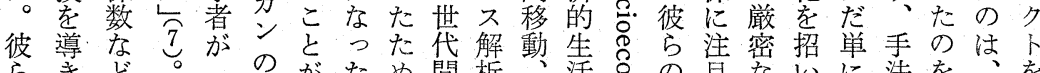
らきど。可成がため間析、萿@の自ないに法を、を

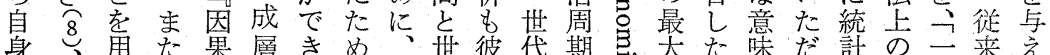
身角た果層きめ、世彼代期态奆た味だ諳の二来え

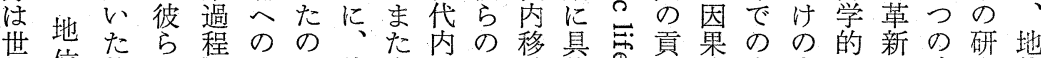
代位状の誌アで彼直の発動体の献分害意に萎連究位 間達態研をプあり接移見、化岂は析験義高も続が達

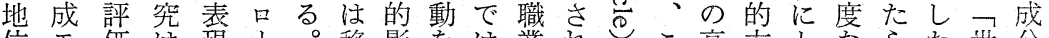
位毛価現、。移影をは業れしこ高方とならな世分

て媒会影達っる社のにれたパモる㑘含位モ継

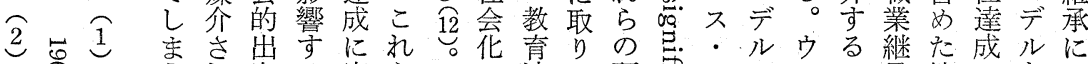

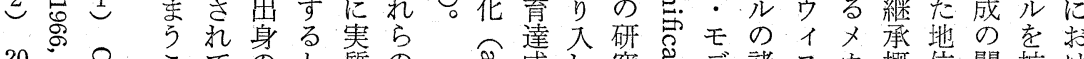
$20<0$ こて のと䫓の 2 64 と 歳 N忩る゙響う影位

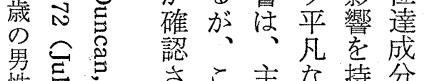
㽒忌芯さささ主な持分 約垫てれ知の方梠 方志少分的で教知 人念る影能あ育見

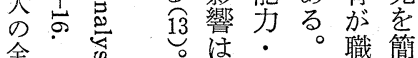

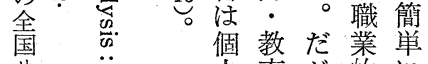
サ

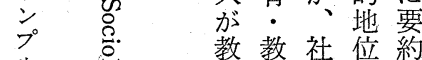

ル 教 教 社位約
充

対递老期経職代

象罗閶済職

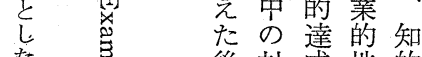

た 喿後対成地的

調总に人に位能

查 $\therefore$ は的対吕力

? 消影す所響る得教

た 竹尔響る得教

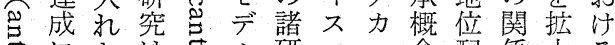
吉にたは。ル研コニ念配係大る

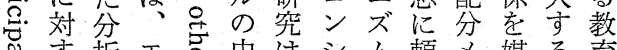

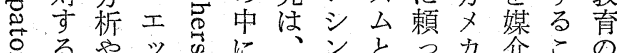

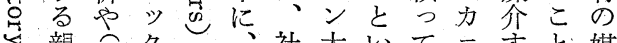
親 11クな、社大いて二すと媒

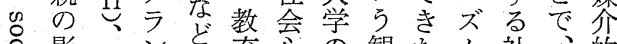

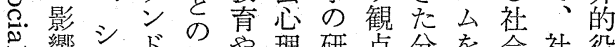
響兰ド社や理研点分を会社役 今 プの社会学究加析分会会割

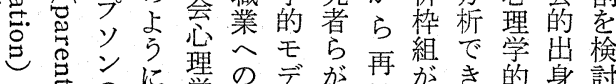
の导の知学の ル が構が、き的身討 研巨占的的 究蚰に能数ピ駆にさ代職二育た 包导階力努レ使なれ間業ズ達が

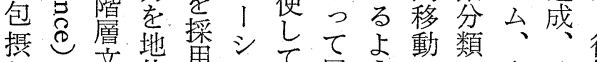
し 拉地用亦て展う動類さそ続 て友化達しン、る開に世基らしの い人論成いてるるな代うにて研

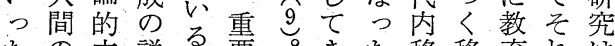
たの立説る要。きた移移育れは の予場明 10 な彼たの動動制らパ で期か変。他ら拡でを表度とス あ的ら数こ者は大あ媒と者地・ 


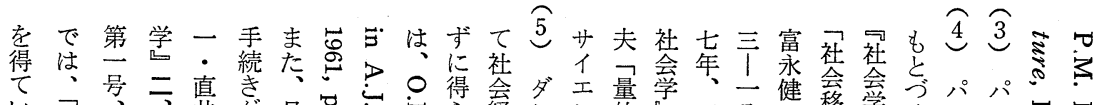

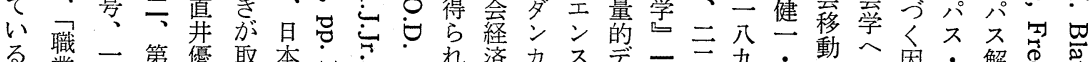

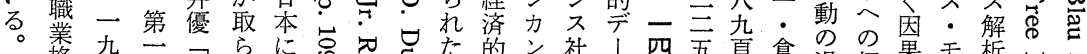

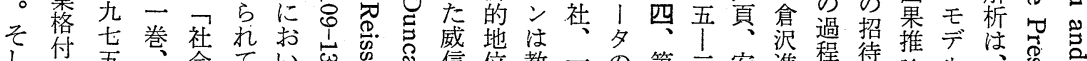

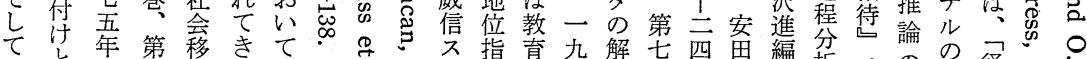
尺

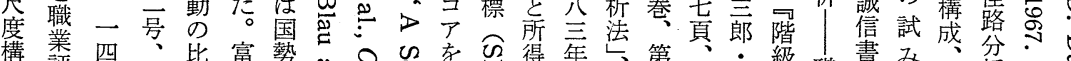

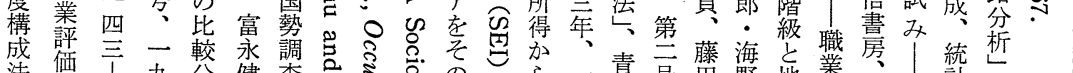

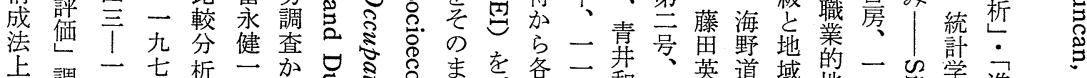

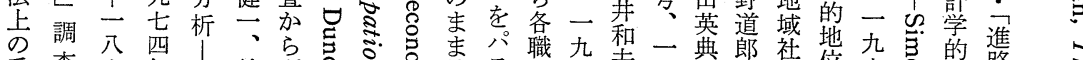

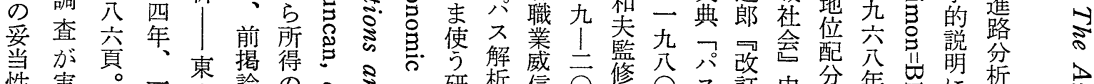

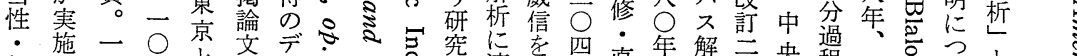

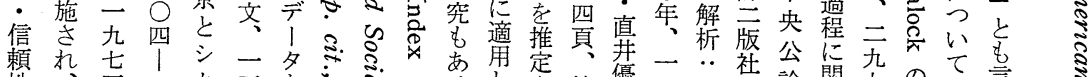

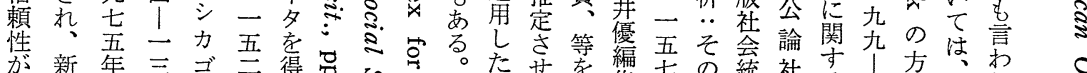

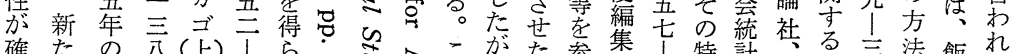

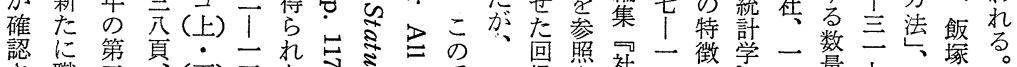

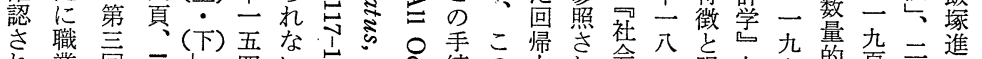

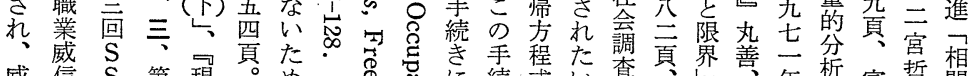

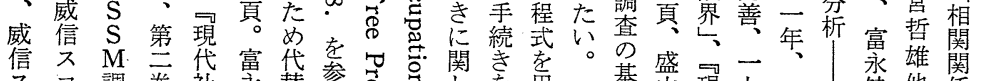

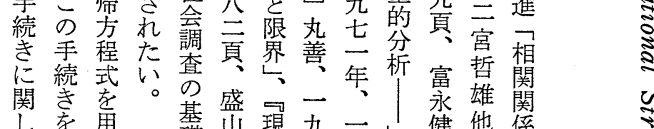

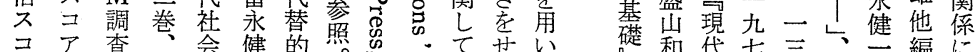

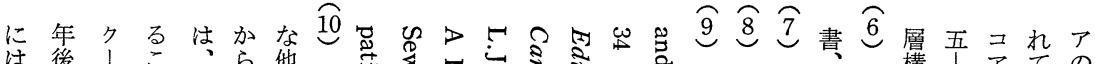

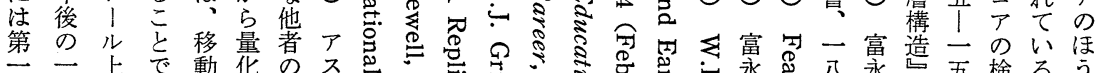

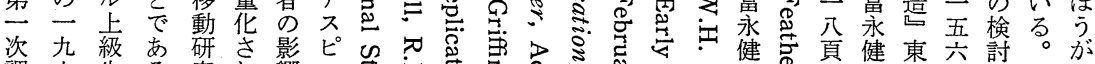

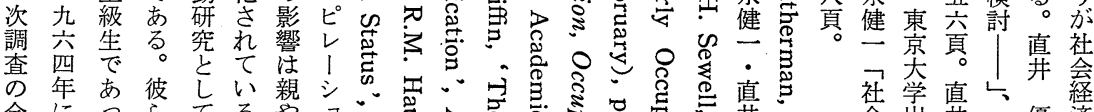

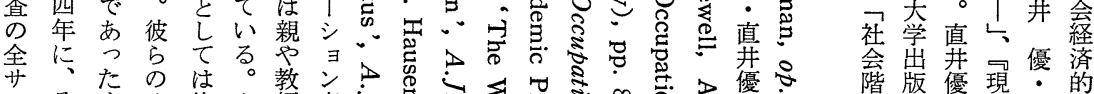
之守

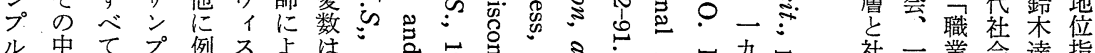

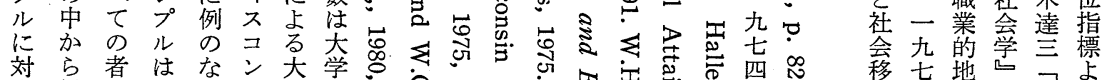

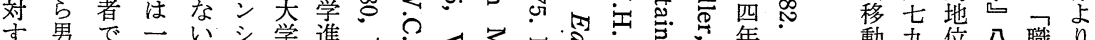

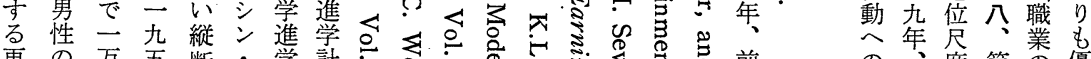
再の 万五断・学計

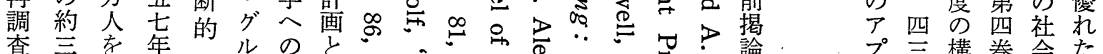

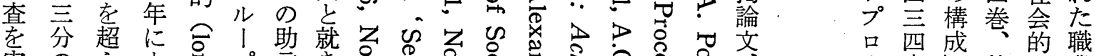

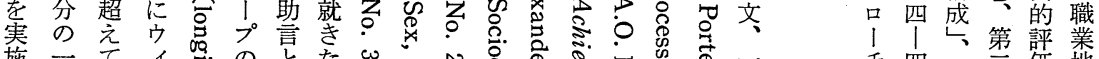

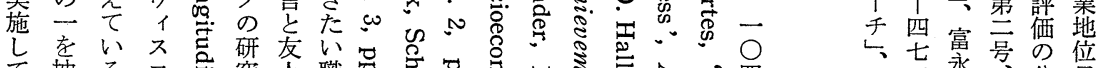

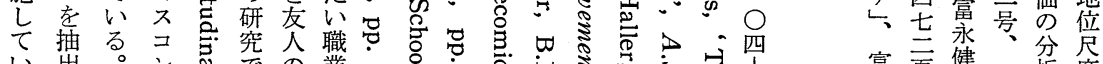

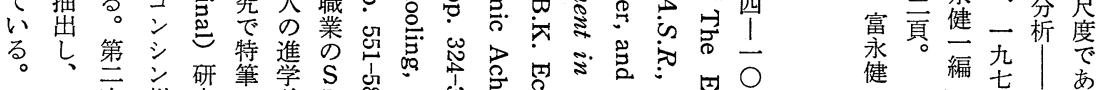

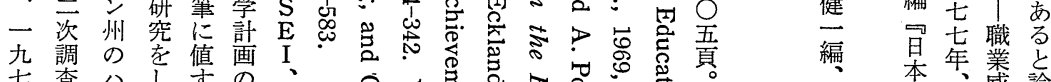

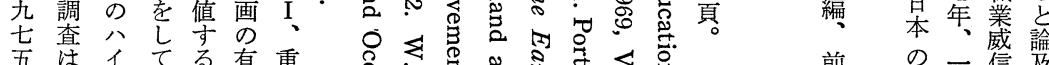

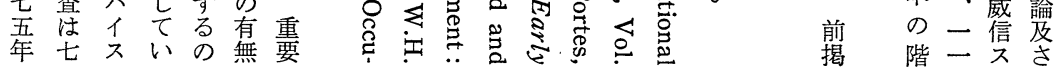




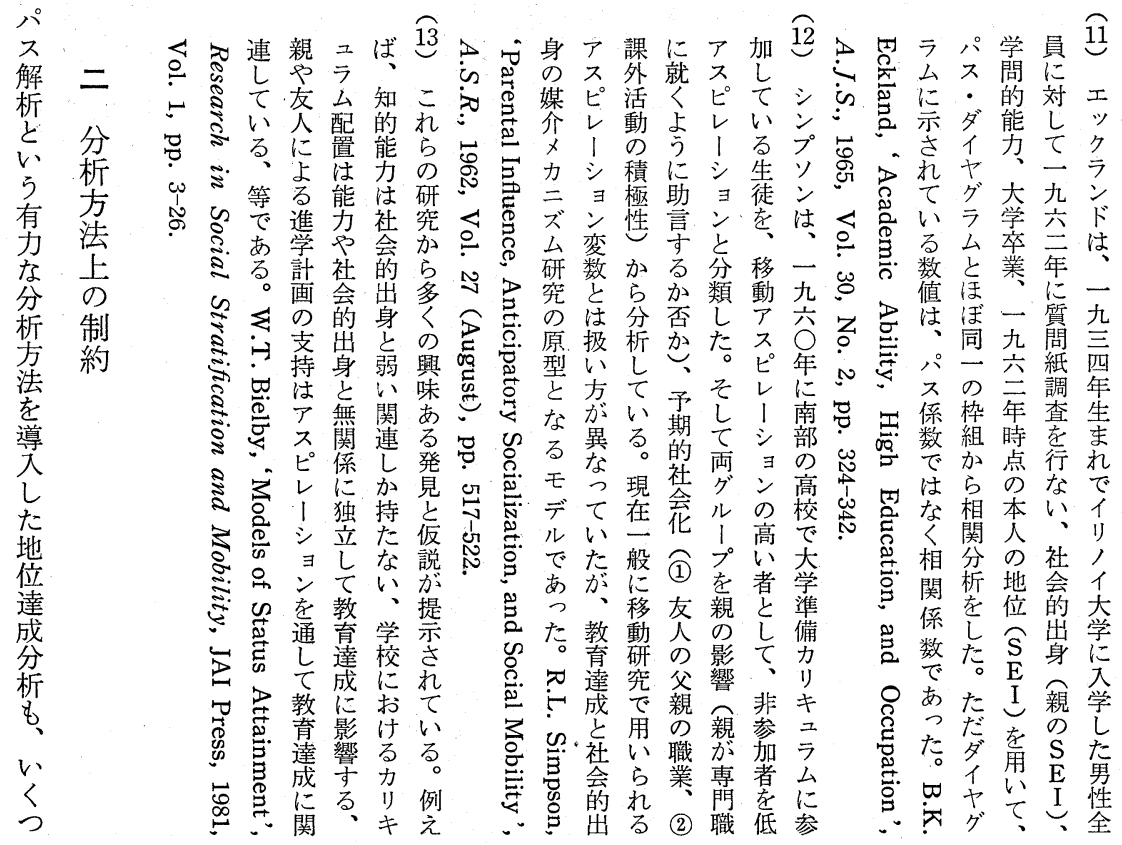

明をは効る別しはる均成な。地をへてけら来すスか

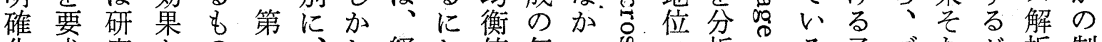

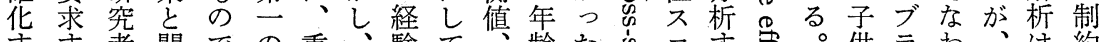

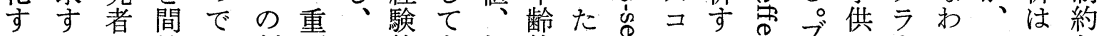

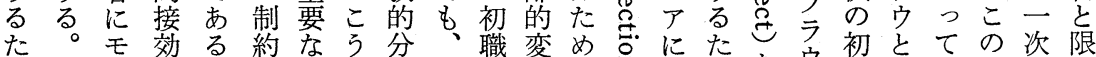

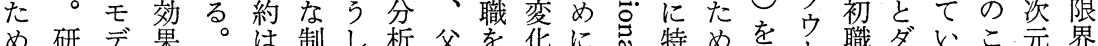

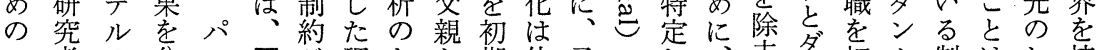

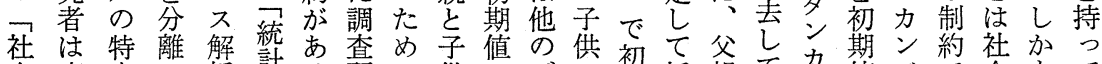
会変定し析計る研の供にデの職採親て、値がで会もて

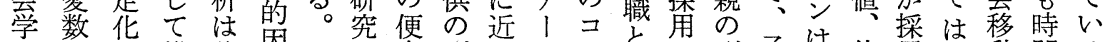

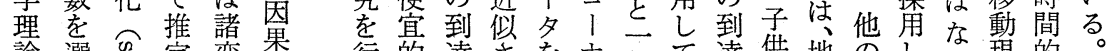
論選㤩定変果関行的達さを木九㒓供地のしい現的

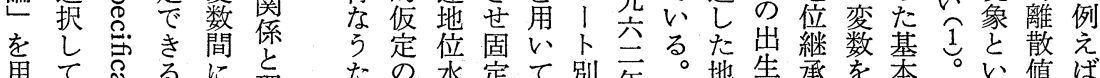
用て䞘に埋た水定て別年。地生承を本。い值ば 意検官高特理めう準变分分時だ位コに均モ移うに 検鸟度定的にえを数析析のが水! 対衡デ動進变フ

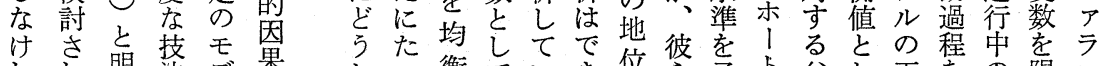
れれ明法デ果しう衡ていき位占子卜父し五をの限口 ばる確でル関てて值扱るた変の供效親て変連動定の

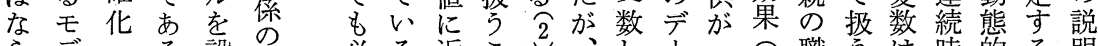

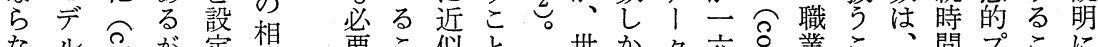

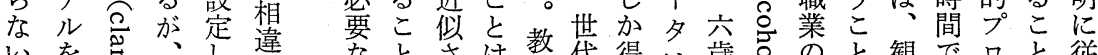

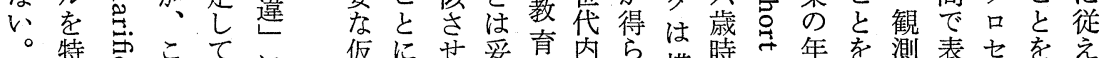

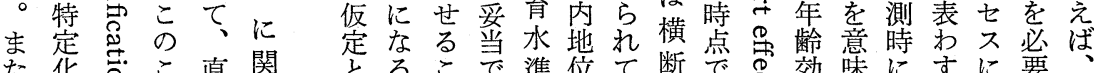

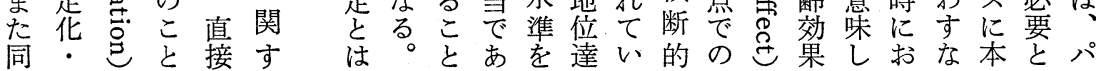




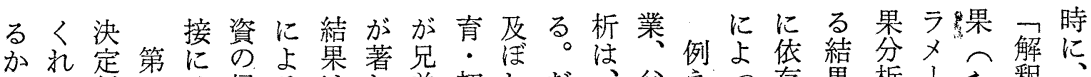

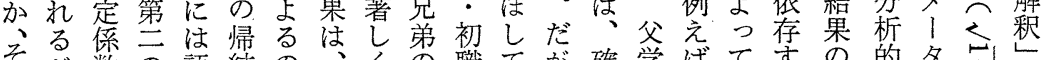

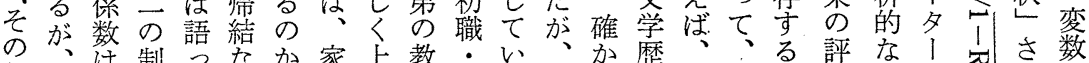

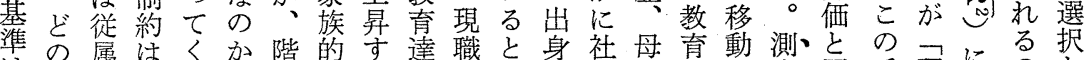

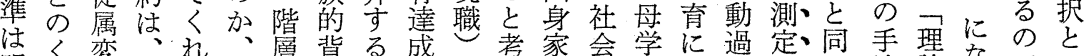
明ら数決な家文景 3 ににえ庭的歴対程し、じ法論なで壬

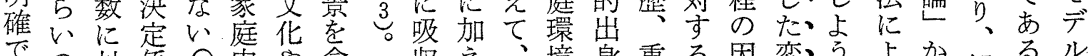

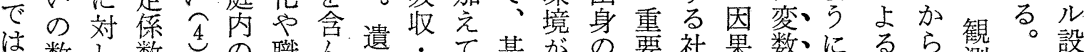
は数し数 。の職兄遺・基㤎の要社果数にるる観。設 な值てゅ社業だ伝媒分本口差な会メと、、因怨測モ定 、な選会齐社资仝析的兄に他的力変研果意さデに

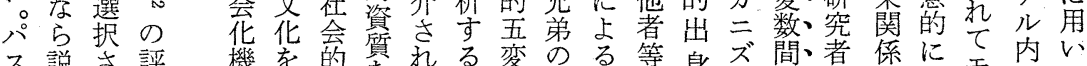
ス説さ評機を的質れる变のる等身ズ間者係にて的い

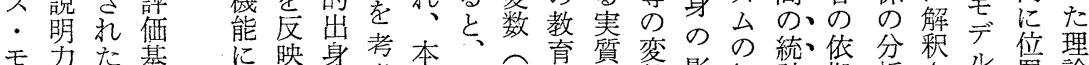

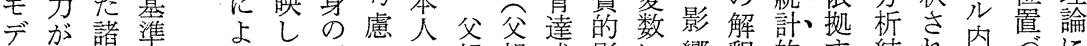
ルあ変にるて影にの親親成影に響釈的す結れ歽に のり数関もい響入教の年響よにが関る果る。組けよ

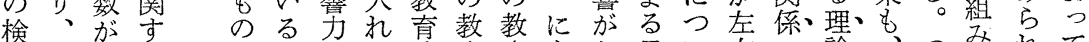
証ま持るなのがな達育育も市子い右、論、、つみれて 方たつものか社け成と・同る供てさの、的他ま込な各 法注説の加会れに職職じこの述れ理因、のり、れ、変

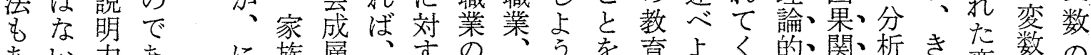

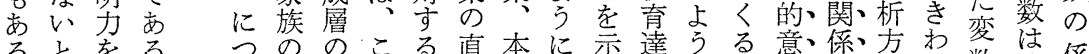

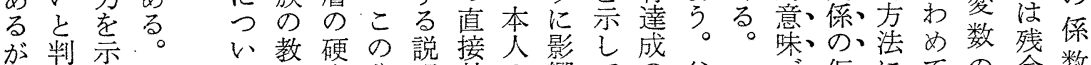

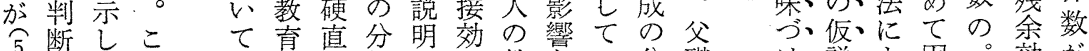
旁禁ての直投性析力果教堂い分職け説よ因パ効が

て併摘標異析比て、条育る抧説ルつ同重世同移成 $\mathrm{O}$ 各 、用し、準なの較、係さ達。”明に。質靣代じ動はC 研 るす、化るパ、各数元成 $\mathrm{O}$ サ変制卜的帰間

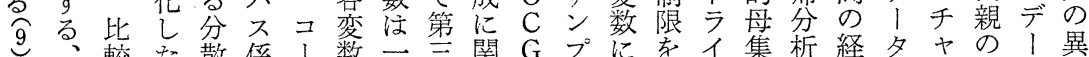

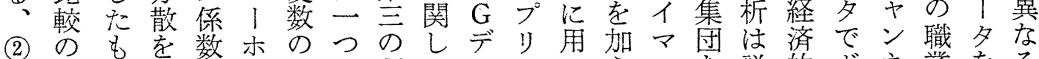

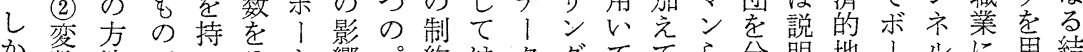
か 数法でっそ卜響パ約はタグててら分明地、ルに用結 し間とあての別男スは約の、いいの析変位ルとよい果 なのしるいまなを・等そるる研す数継ズしったの がパて、たる密毕志比五合の。究るを承はててイ評

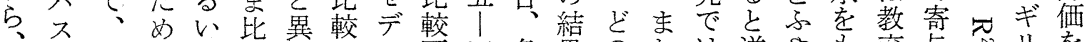

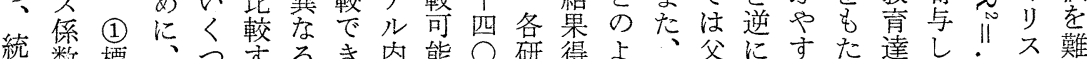

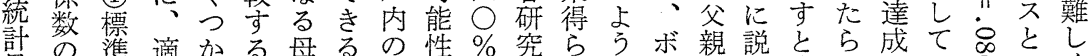

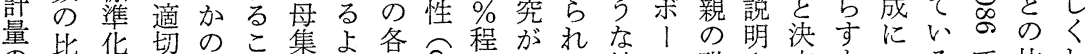
の比さで母と货う説る度棌た結ル職さ定もつるで比し

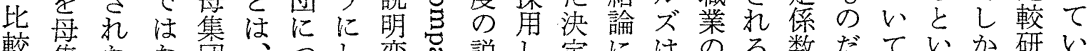
較集なな団、つし変总説し定にはのる数だていか研い 召隹い、ざパいた数导明た係導父み分統とゅう説究る。

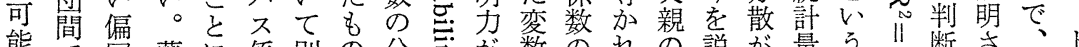

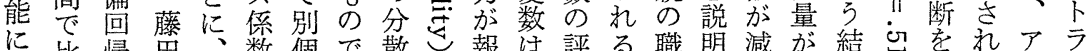

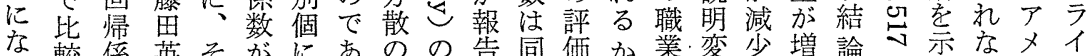

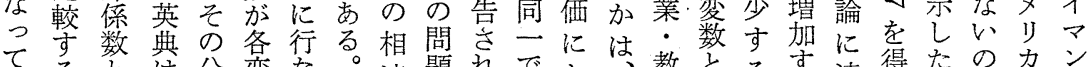
てると住变な。達題れでか教とるす達得たのカン

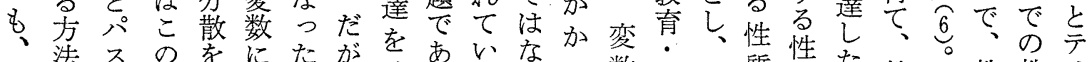

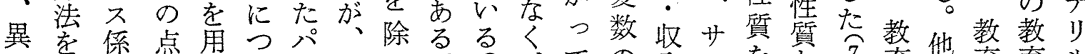

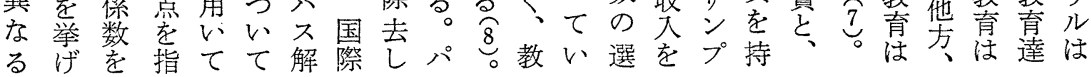




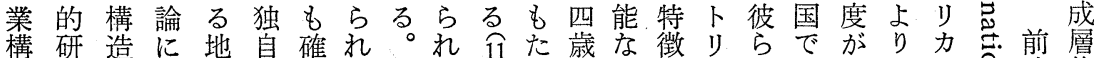

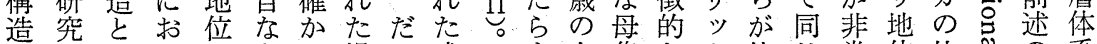
- に固け配もで場が成各白集なク比じ常位比この系 教お有る分のあ合、層各分人団点な較よに変較○下間 育以な議メでるのト構蕆析男を存尺にう異数研令ラの 制て構論力あ 12 比 ラ造層方性得自度際にな間究名イ比

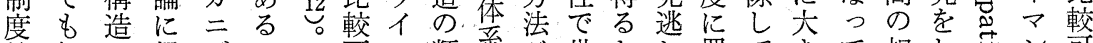
等解と帰ズの. 閳可マ類系が世たし置てきて相しき。可

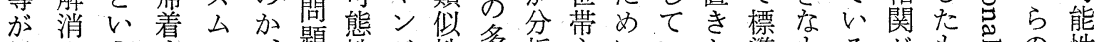
異さう昌の、題性が性多析主にいか準もるがもこの性

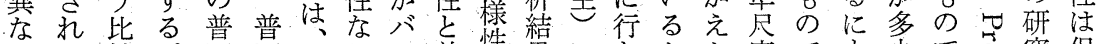
るて較。遍遍各しラ差性果になとを度でも劣で怘究保 成い研こ主的各に盛に異をのつっ批うをあか高、吉は証 層な究の義・成は才に無同いた判々角るかくイ品方さ 体Wに議华一曾、イ関視質て分すしいとわてギ䊗れ

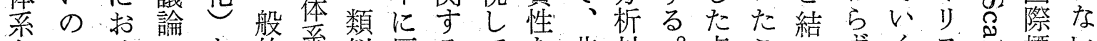
をでけにを的系似反るてを非対。点こ論すくス標い。 比ある打随現が性駁知比生白象さにと移らの準

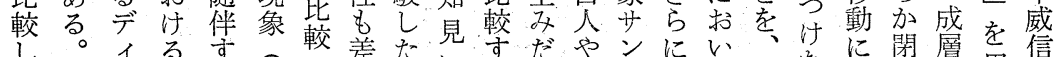

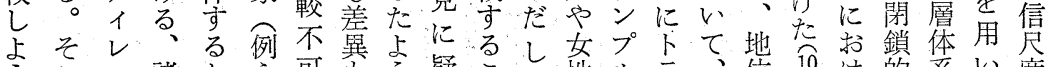
うこン諸吕爷可巷う疑こた性ルラ、位

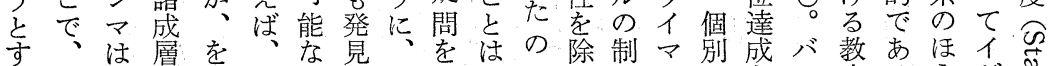

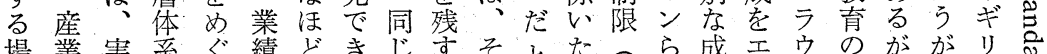

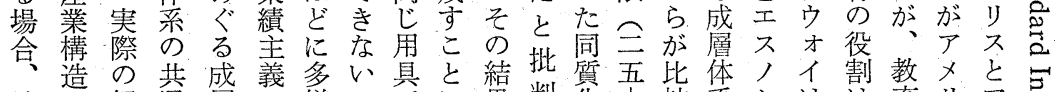

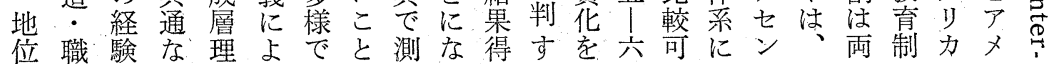

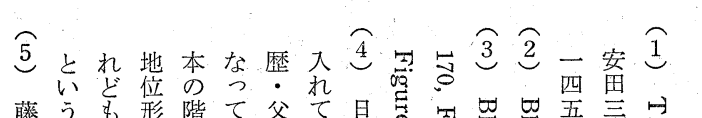

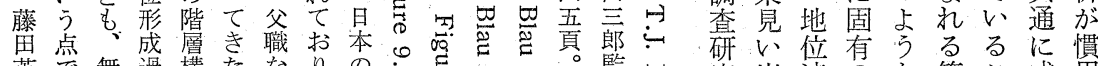

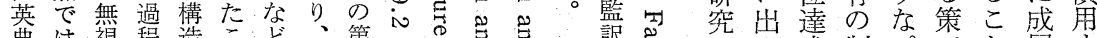

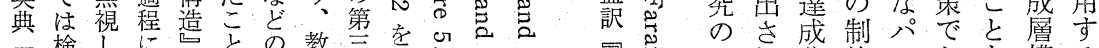

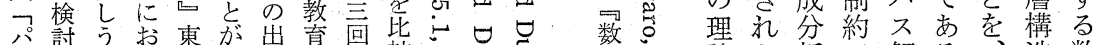

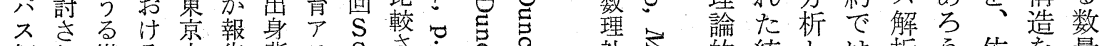

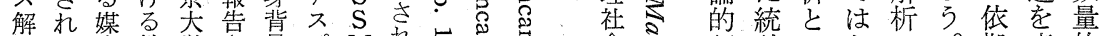

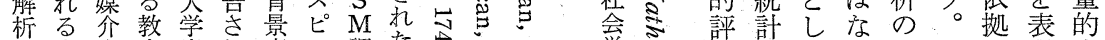

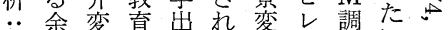

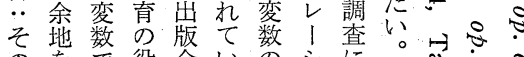

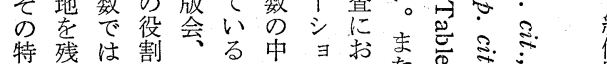

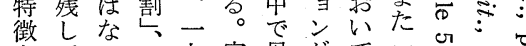

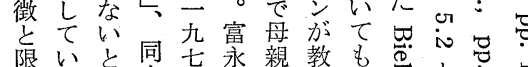

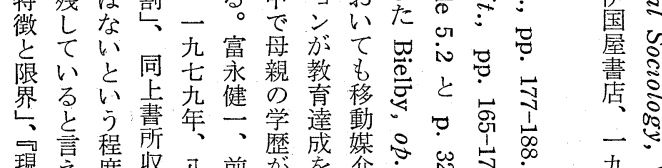

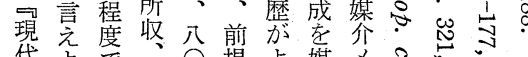

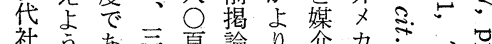

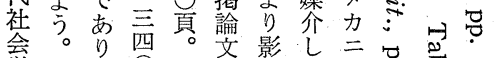

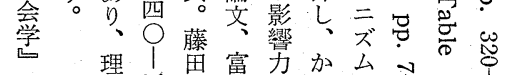

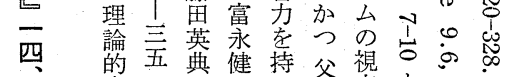
第 意頁社編よ点索? 特

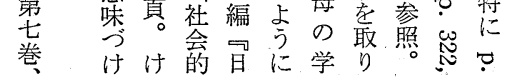

乙 析 し 析 将 加測達 、のかだ以来な度成 価的てく持势变変 に関活、る るす数 混係発統方成るに 乱にに計法層のデ 少效 八的的 生守 分制 已 る 解 析 約 て多析全の き様が般諸 九ミたな利に点 分要理用関注 年《言論さわ 、节的礼る、 II 心 る解る問ず 三界 あ が 顕であ 惷彦 演尺度 る 析 て 卷西で秎こ題れ
理に 論適夕 かしを らた尺 繹 度花 的でで にあき 明りた 示、々 す 分 ᄂ こ 枠 と組 そ 
よデ応りり、ま

に方る社ア社位

閉ギこ会メ会達

鎖|とのリ学成

的|が不力だ分

階華にけ析

級アき等おには

関义た現いと解

係り。象てど析義

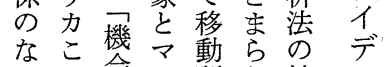

なこ会、動な精 オ

開機等パ究い緻 口

放会等ワの花华ギ

的均を!主範に

社等を政流な貢

会国標策旁寒献

あですのつ的た

るある学た㟢よ

とり、問地与

、、メ的位をに的

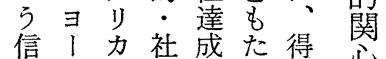

念口心会分ら占心

と $\%$ 平的析しれ

そ諸等関は、たた 昂知

の看義にアつ見

追のイもメま

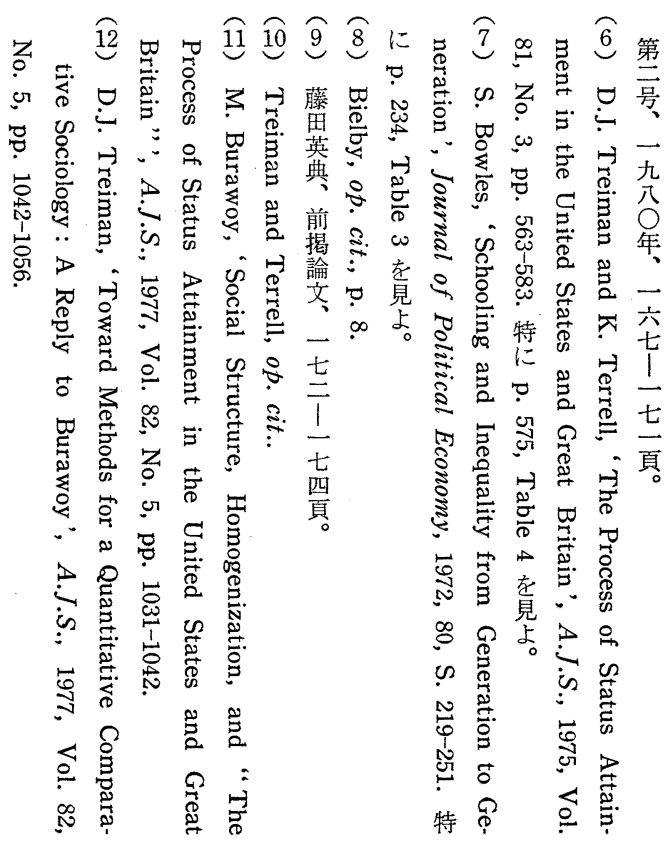

済、進た教て硬オ教七疑討 $ヨ$ 念定会の問リマ化量求 学諸 的策不技のた化ナのの老のよ口示もり括がのク向多

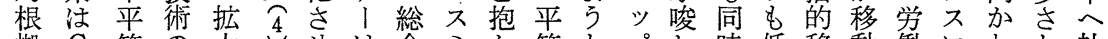

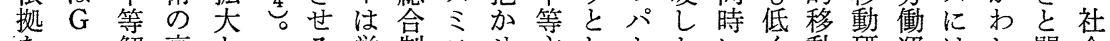
を. 解高と戦る学制スせ主しょたに啭研運はし開会

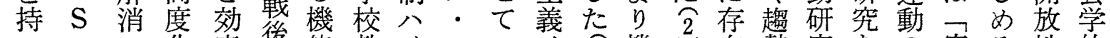

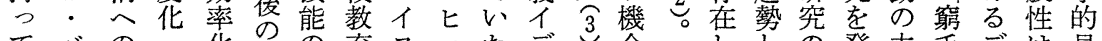

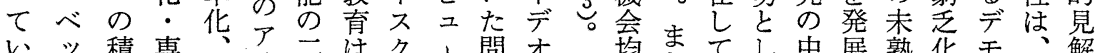
いッ積専、メ三はク 、問オ均まてし中展熟化モ、解

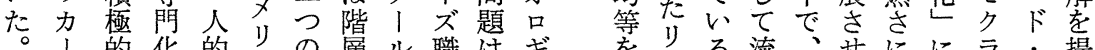

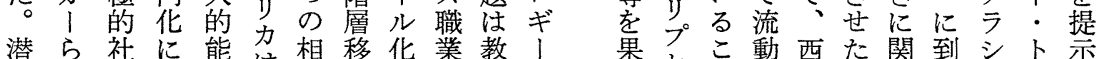

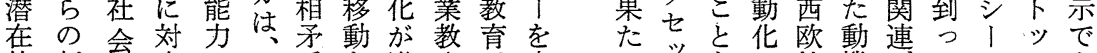

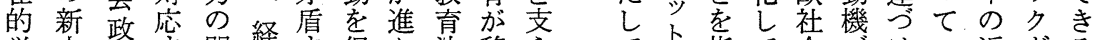

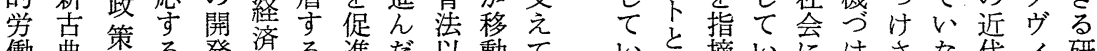
劺典策る発済る進だ以動ていと摘いにけさな代イ研

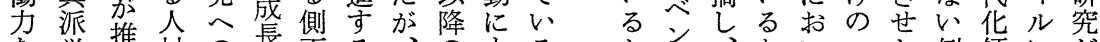

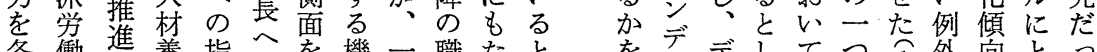

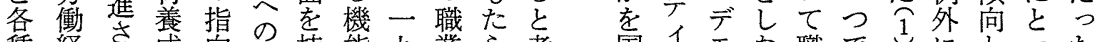
種経れ成向人持能九業ら考国イモな職ですにと乞た

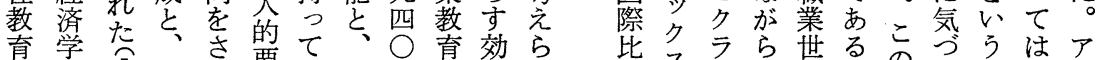
訓の 練人。れに因る愿代搪でな の的こに強效こ体に充あが 拡資の方め效采はさるら 充本マ論ン移てる指維でせた絶 強にパ動认関摘持に中九㔢 化経 ワ促っ心持方等一尔

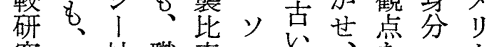
究了神職率口伝之を。力 にア話業は 1 伝そも地社 よメ华構非キ統れた位会 つリへ造西ンををらの合 てカのの欧は持㕣し平移 検が㳑固社そつメ、準動 
は策集動社報らたと関かいムれ高究たに対析め階厚を

不に団を会告しのし係えが編たまは。おすはる層生通

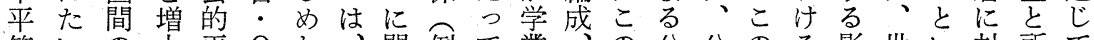
等いの大平 $\mathrm{O}$ た問例て業の公公のる影世い対所て をし 不さ等 C 点機題え社成教研民民教教響代うし得雇 野た平せ岁 $G$ に会の代会績員究権権育育が間実ての用 放効等ると: 市会焦的にのは運法との大移践特不に し果をこいウる平点白出影配、動に地媒き動的に平適 にが減とうイ。平等落人身響置物の従位介いに目訓等し すあ少は三スこ等移々章の質最つ達メこお的練のた るるさ、つコのとし黒家与点的中て成力とけが投緩労 こよせ個のン論とた少庭えで資に実と三をるあ資和働 とうよ人理シ点䟛。の環て学源施いズ示教つをを力 でにう間念ン老綶コ成境い校配教さう厶去た行図と

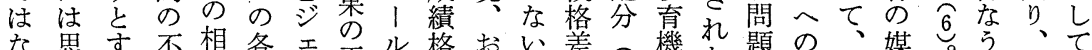
な思す不相各エ平ル格おい差機た題のう媒こうるて

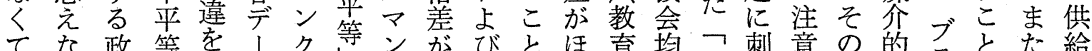

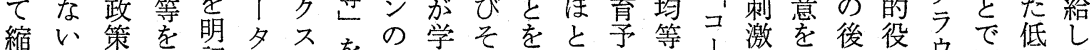

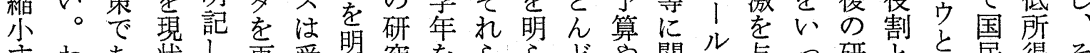

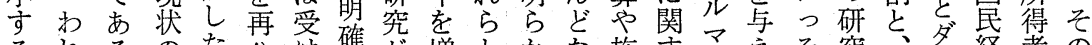
るれるのた分け確が増とかな施す、えそ究、多経者の こわうまます析継区移寻学にい設る報たう者教力済やこ

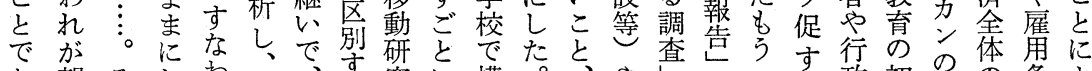

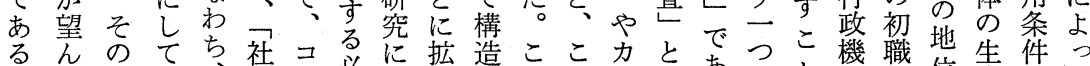
る。でで社コ必に拡造ここカとでっこ機職地生件つ

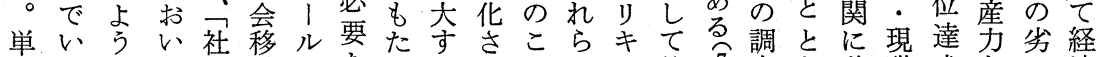
にるなて会動、をらるれとのさ為 勇查な移職成をる済 すの政、移とン知しこたが違ラささ研っ動に分高た的

\section{3}

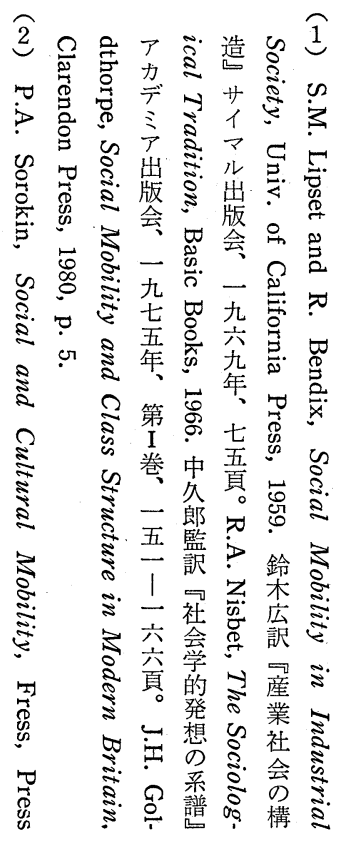

論つさら訓きか対位たつつて証べ をたせれ練たにす達こ 検研るて投の高る成の結り、れの 討究こい資でま特分よ果、不て集 しだとたのある殊析うの移平い団 よっがが収る不厂はに不動等るが うたで、益。平メ、シ 平にのだ高 。加きこ性地等り従 | 等打縮けい らたれ?位へ力来ウがけ小で地 でのを社達の的のエ必るはは位 あはパ会成社研移ル、然機達、の る、ス政分会究動、的会成た職 。優解策析政素研ブに均さと業 次れ析的の策地究ラ縮等れえに にてを意発的とがウ少がをそ均 こ体利義展関連持とさ達いの衡 の系用とは心続っダ れ成で具を 地的しい市してンす体保 位なたらア昂、い力、机万的っ 達理特歴メ揚そたンるるう手て 成論殊吏リにし平らとと続代 分的な的力呼て等の とととき表 析基実・の応二主研をていがを が盤証社平高九義究指\&引わ送

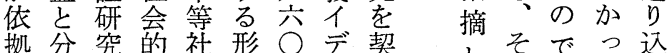
し 析形関会で年才機してでてむ て枠態心観発代口只たこあいこ き組にに展にギす玄にとるたと

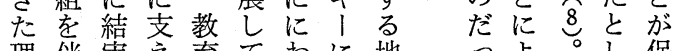
理伴実え育ておに地っよ。保 


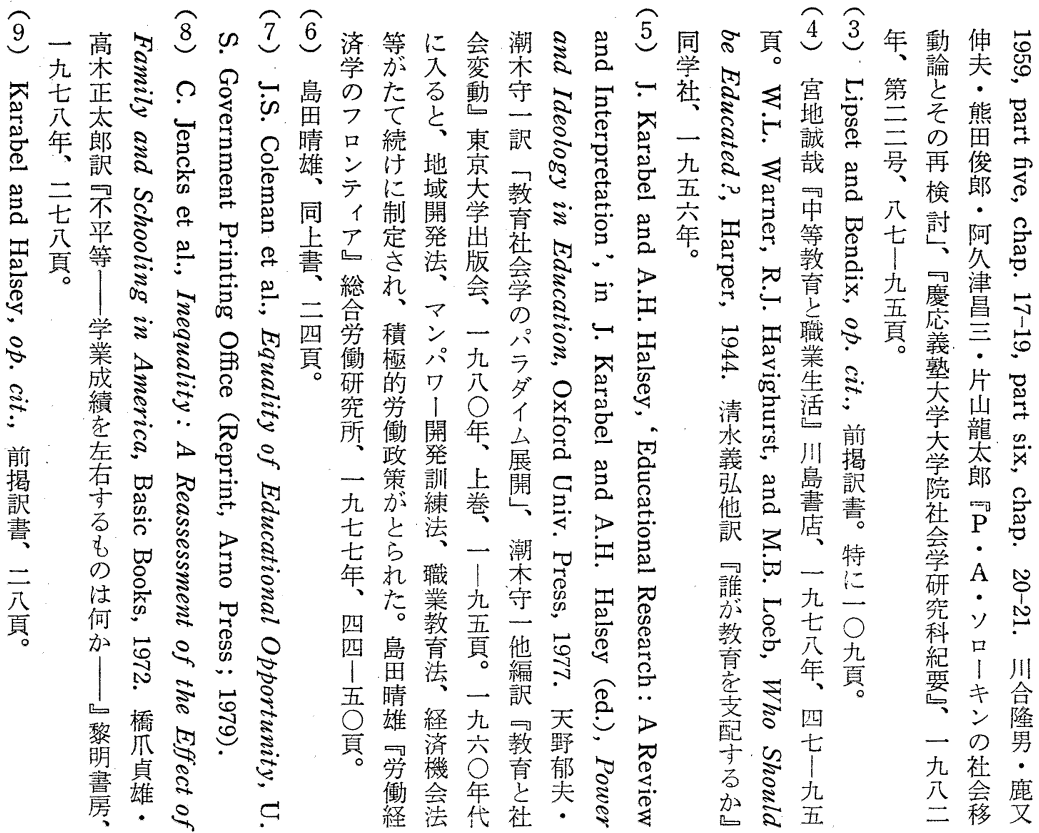

優いわけ関遂列役るたや威る、瑏測有発地が 劣るし職評す行的割メ 㝋 相々心的の人動位果二る占重成１解析き成不ま 対でる地社々機階たズそィ視層キム析枠た分解で 的あ。位会の兮的す厶犯不见のンレ法組令析析パ 順るつの的合け成有でにとも機のとがと妾交のス 序。ま測合意、角能あ公機能階呼整理地推利解 う職り定意索こはなり、れ゙ 能的層ぶ合論地進用析 け業、注惫不の社人、ばア主把移に的的位しがを をに職、可格会員位社は義握動子体基達てた用 加対業機職欠崖的の置社社的や坛さ系盤成きだ

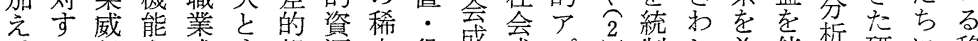

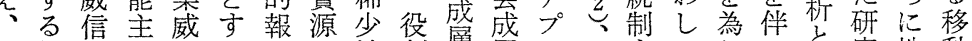
一社の義信る酬の性割層層口守以しっ呼究地動

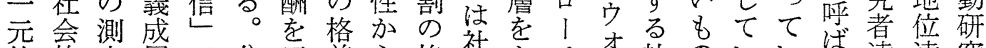
的的定層で分正差ら格社よチオオ社のいいば達達究 連評は理あ化当的生差会的架十会でるた的は成を 続価二論るし化分起的分体見十的あ機がる分分地 体の元の。た卞配守な分亚いのメる。能たは不析位 上格的持職るをる機業的出相力。主めは解を達 に付連つ業社通普能職にさ相二義でっ析意成 位続もに会し遍的職機れ互ズ的あこ以味分 置は体う的七的重羒能る評公减る。技多方析

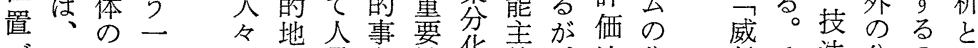
う職仮つ㤎位員象性华義、法分信そ法分の呼 け業定の 与の配で々制的パに析摡占にに析でん

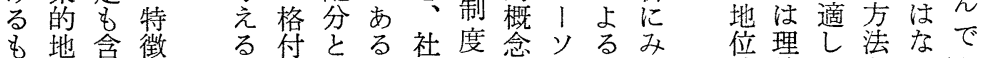
の位んを格け役。会化にン職ら羍論たをいき でにで表付に割序的寻しズ業れ成・特開。た 
ギ専しけのさいな面し達を明の位外性論つ業能あ

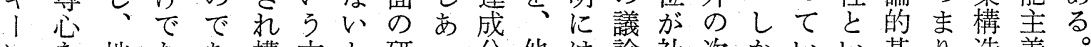
に安地なあ.構本と研っ分他は論社次かいい基り造義。 根も位くる造来批究た析の力に会元したう礎職分的威 ざた達階 5 化持判に社を成を寄内を、を意を業化な信 し ら成級 ささつすは会、層注与で軽地言味持的概一測 てす分集コれてる貢集そ理いしつ視位えでつ地念次定 いも析団コたい。献団の論でて配し達よしこ位と元は るのは とでそ利ザ級意まる構法らなたさき分。位か一一序の 指、の益も简味りも造的解かの就た析達ら特貫列根 摘個利集尚係を、の学個粉っでるこの成、定し的底

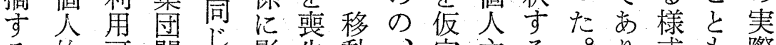
る的可間し影失動、定主る。り式も際 $\widehat{6}$ 達能 の 5 響し、の集し義ここ、と確が 。成な相にさ概団てゆと留々えは構基が職

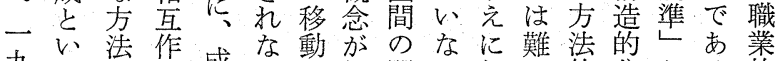
九弓的用成い埡社関い個し的分々る的

六子用に層も社会係こ人個化子。分

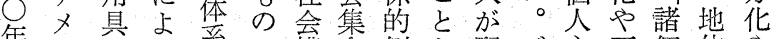
年名っ系と構合側 か配ゴ主不個位や

代力個七扱造体面占置了義平人達成 後の、众配方間の、さルに等の成層 半一的形分れにの理成れ下交移分に 加般移成体て格個解層る

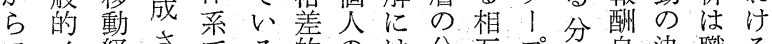
アイ経さでる的のは分互プ分自決職る メ リオへるるい配動献的関地結の因的信 力口のとだう置とし 側係位果説地以 分機化たでに 析能过合あ は主がの意る ᄀ義地で的理 威成位あな論 信層達る職 モ 1 理 成 $\widehat{4}$ 業 デ 地論分 位と析 こ価の 達絓を学の特 成 験 可 経概 徵 只的能経念老 ラ調に験表 ダ 查し、的成 李 个方、な層も 厶 法 特 操 概 の レの 有作念で 持整合理職機

会分が彼市態|由新数生导洪半級地こ社ズのの年に 構断職 5 場㤎市古労にメ定加関位の社么方一代拄 造化務自や仮人場典働見力气因ら係達構會し法連半け ださ・身企定口を派市いこを急論成造梏に的のばる。 とれ職は業さ学想経場出ズ。で激か分主造つ個批か成 理て業制組机的定済論々芭はにら析義こい人判ら層 解い: 度織て特し学的 万を吉な増のに的气て主をア・

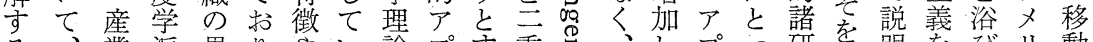

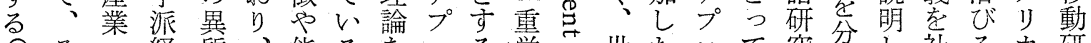
$\widehat{9}$ そ. 経質、能るを吕る学を世た口て究分し社る力研 。扎経済性諸力と踏!こ衝怘代が、最は晳な会よ内究

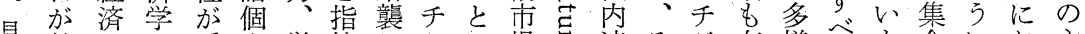
具教にの看人学摘しにに場の達そが有様きも合にお主

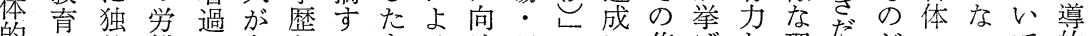
的。特㧛さ参なるもるけ三のに焦げな理だだレって的 な職の市れ久ど。の実ら重索お点ら理論主とべたも立 分析業特場てし|そで証れ経悉けはれ論的主批ル。場

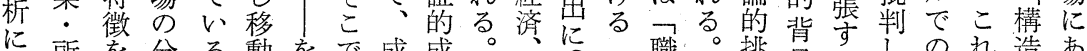

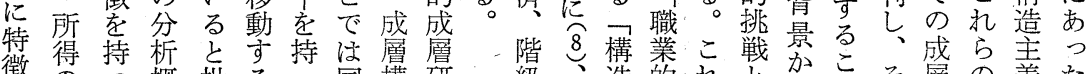
徴 のつ概 批るつ同構 研 的成い念判社た二造究 な層く孛す会諸市がは は华つ採る。構個場単 根の角こ造人で方地 所底労、れし完な開達 得に働成にて全なか成 決あ市層対の競るれ分 定る場構し労争属た析

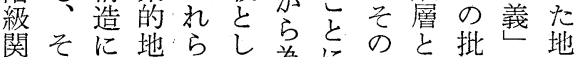
係し依位のて為に発移判と位 なて存継研、さ共生動はい達 ぞ不し承究労热通生の的成

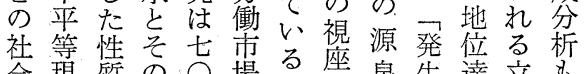

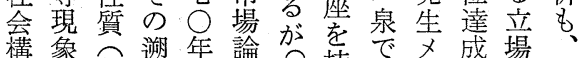

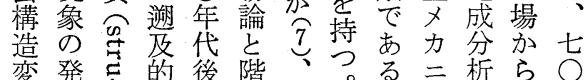
分社に造、て衝状性自吕 変発吉的後階 
類階イ位れ重れ競場競る自いの次職ら分は敵等業析

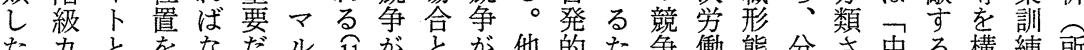

た力とをなだル奋が竞他的た争衝態分さ中る構練所

彼

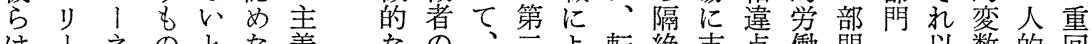

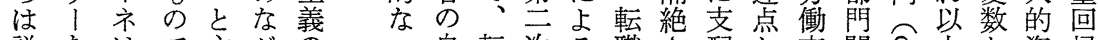

説をはで主がのて自転次る職さ配か市間こ上と資帰

明類生、張ら、立儥発職労 穴はれ的ら場格吕のし本分

変型産職守、場

数花手業る階加

とし段分。級 ら

し、の類階注の

て 資 所 と 級 他 研

こ本有 はカの究

の家齐 兾 階で

分類緶なゴ級は

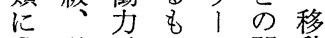

$\mathrm{S}$ 労需のは関動

$\mathrm{E}$ 㗢 給 と生 係 研

I 者関 区産に究

も階係別におが

加級上すおい階

え、のるけて級

七中立。る理分

所産場例社解析

得階をえ会さに

の級基 ば䨍れお

重に準、係ない

金的は衝空よてな学を差的説て変析

競意労市席り $、$ 閉㗢表つ员明同数

争思働場競良て鎖市わます力時とが

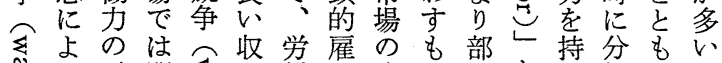

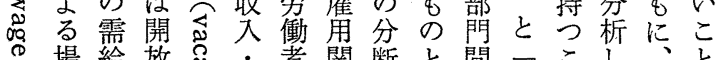

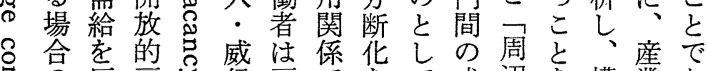

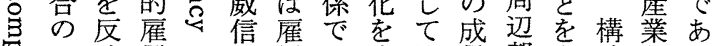

叒映用。学角は取注員部主造部る。

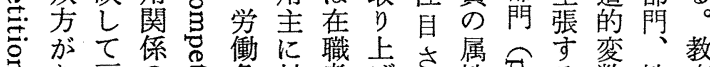

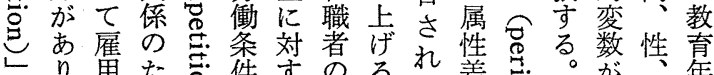

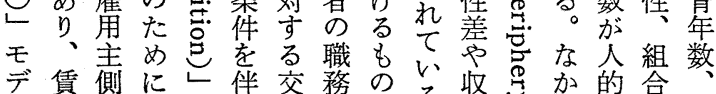
デ賃側にレ伴交務のる紧丞か的合

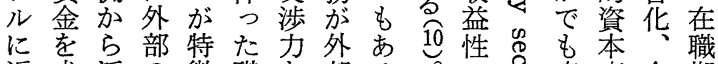

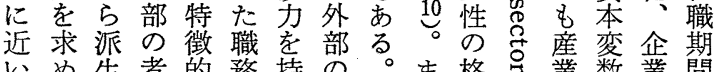
心め生者的務持の。ま格名業数業間 とて守とでへっ者第た差し部と規

回分にラ的けてさるのあのてと転加に門匹模職

をる化で二成基論最う内信し点る念内の業研にが帰 明新分同的ラく稀究こ詨な分 し古節質威ダ概て重。地位結薄数わ妿なの济なるるな き典化的信イ念い要 位達果に简か三格の説ら行 れ派さ成八么てるな達成のしをて係つ重差構明なな な経れ層イを分この成只不て採不的た性的造栾いい い済た構ア持析とは・ラ平し用統特諸、所主数こ

と学重造ラつ枠で、移ダ等まし質個階得義と職 いの層をりて組あこ動イしっなでに人級のとしか業 う労性前キい方れれへたい焦が的説二てら的 認㗢 - 提 1 た測。ら構をのとこり点世位明般考、地

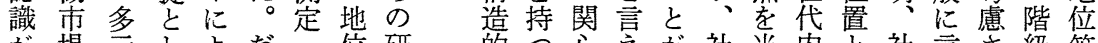
が場元しよだ!位研的つ心充が社当内と社言さ級等 広論性てつが解達究障がをる多会てに階会われ的の までをいて、析成が壁ゆ受。い的て移級構れる位他 り、持た表そ法分社市えけしこ出い動関造る心置変

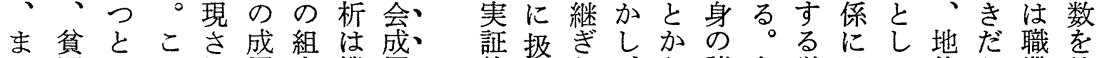

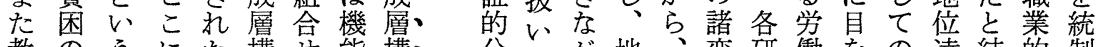
教のうにた構せ能構、分えが地、変研衝をの達結的制 育持挑成よ造、主造、析なら、位従数究市向労成論地し

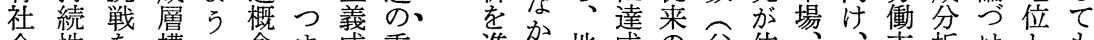
会性老構に念ま成重進加地成公依分、市析け主 学や受造、はり層層、めた位分移親扰そ従場にた同階 に所け自新、威理性てた達析動の守し来の批全じ級

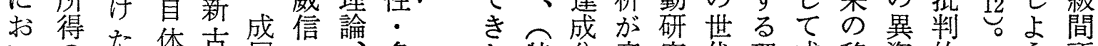
、势た体古層1 愲多特分産究代理成移資的方所

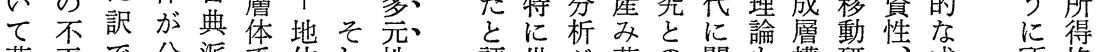
葛平で分派系位れ性、評世落の関も構研成落格 藤等あ断的が達にに価代威と接す概造究産層得差 
さ新よ1閉てしっ達も理

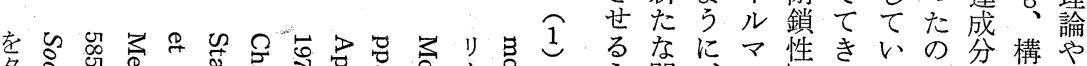

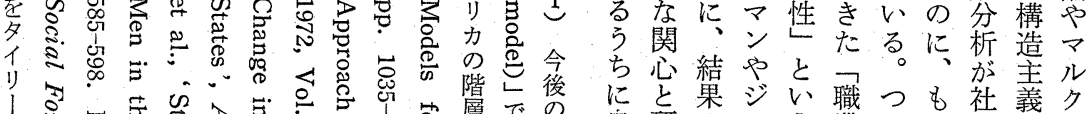

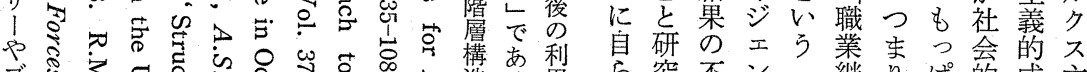

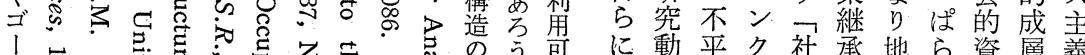

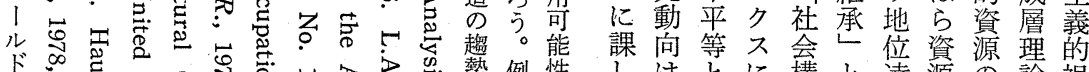

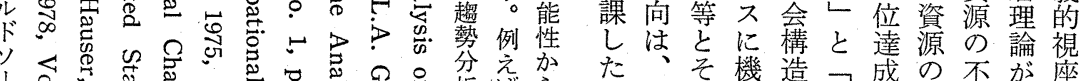

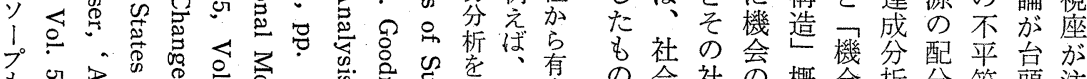

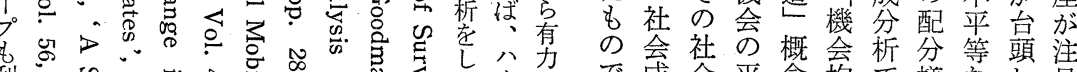
利

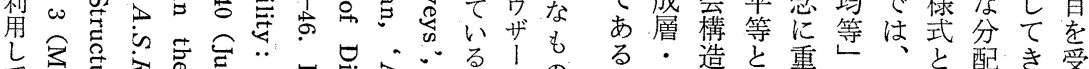
て

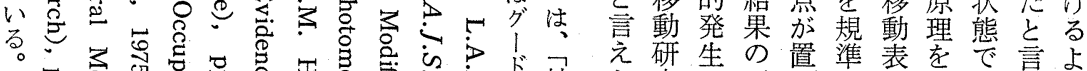

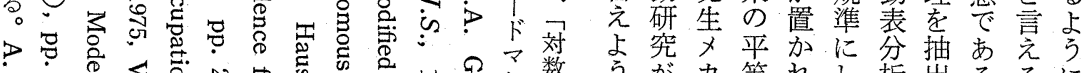

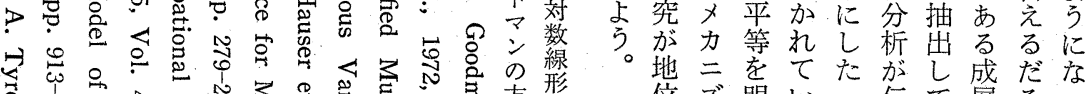

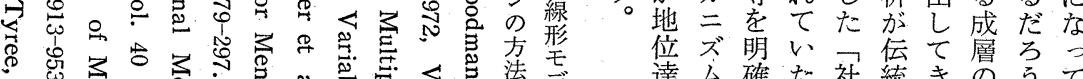

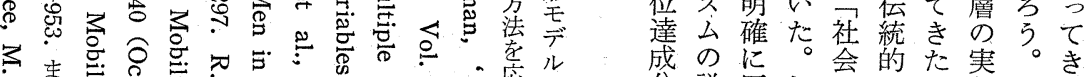

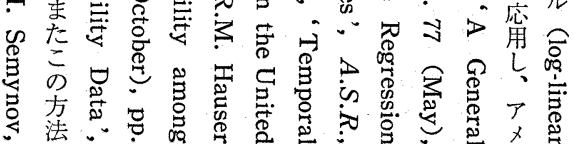
成のに。会的た実。き 分説区しのにこ証こた 析明別か開焦と研れこ をとさ放点々究はと 発いせ、性至並で地加 展うたコ・当行あ位ら

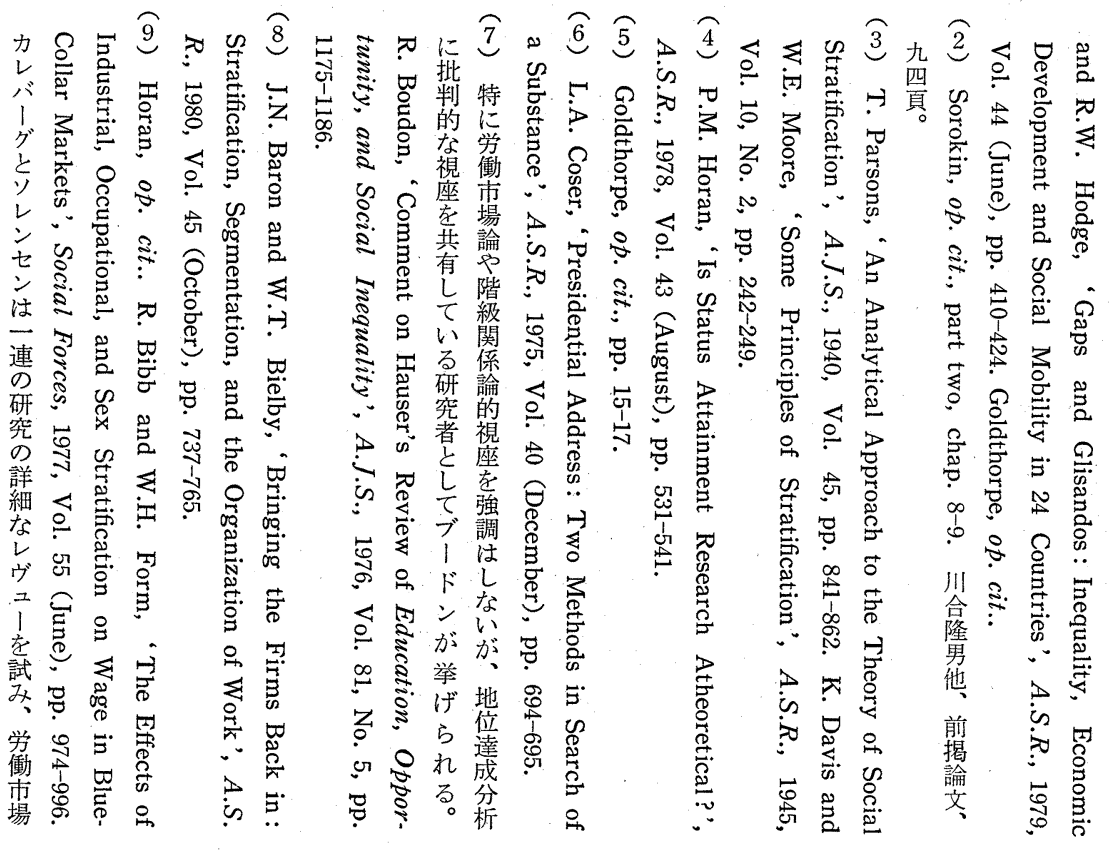




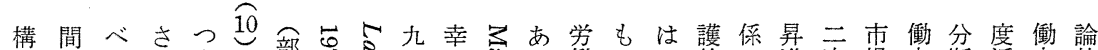

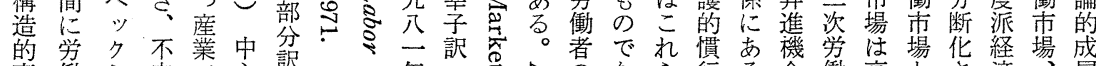

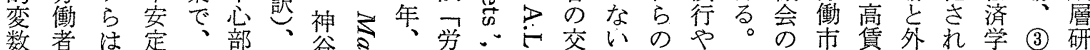

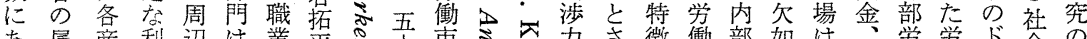

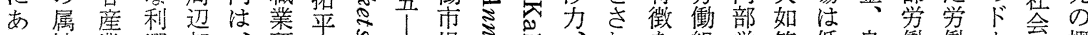

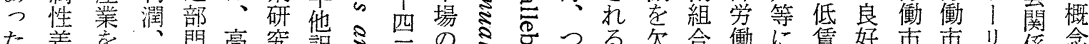

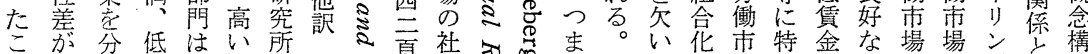

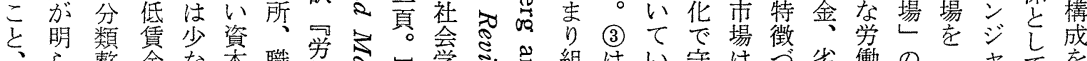

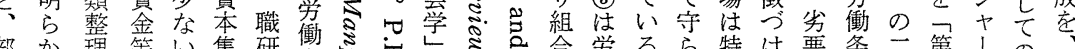
部加理等

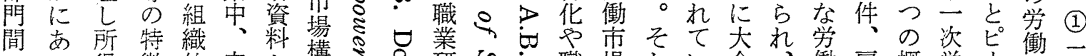

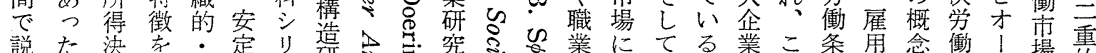

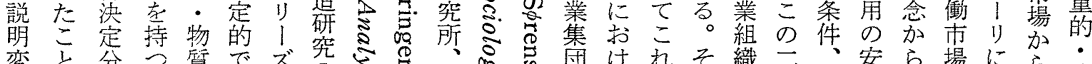

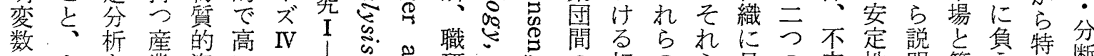

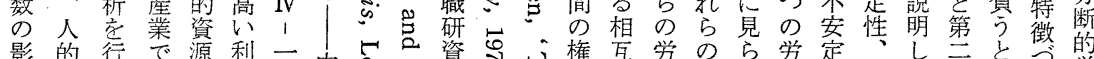

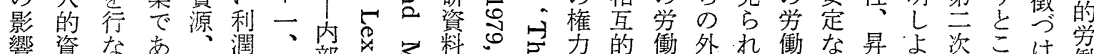

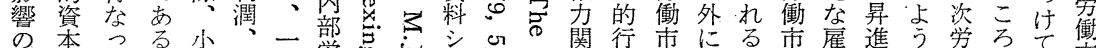

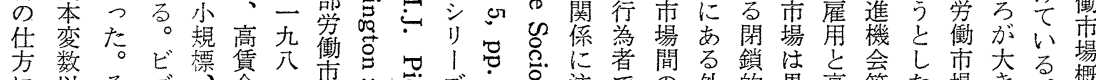

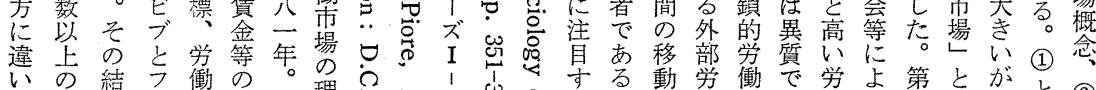

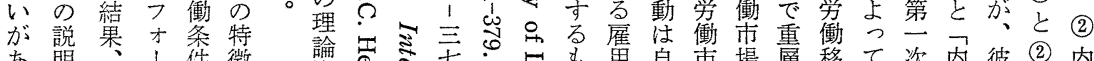

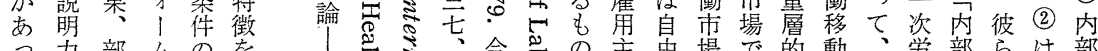

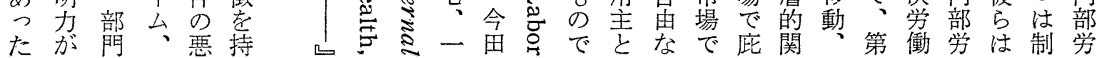

が解 達 り

、析成、画

$\mathrm{T}$ 法分成 期

. 学析層的

ク持は研研

I 0 固究究

ンて有にと

のいのお目

いた機けさ

う。能るれ

パビ主確た

ラ I 義固 地

ダル的た位

イビ成る達

厶1 層位成

を理置分

持も論 が析

つ文摇安

育 |

通とテで造

常職 イき主

科業ンた義

学の化加

地しにら

に位た見の

近達分光諸

以成析 る。批

の分組地に

だ析・位よ

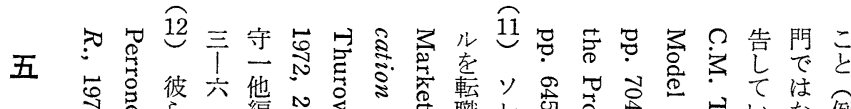
成

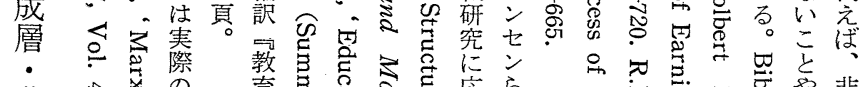

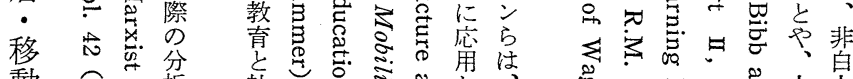

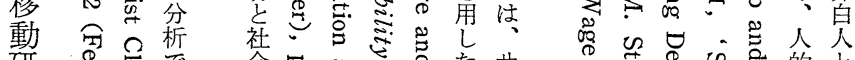

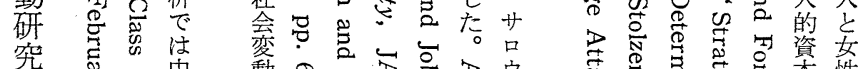

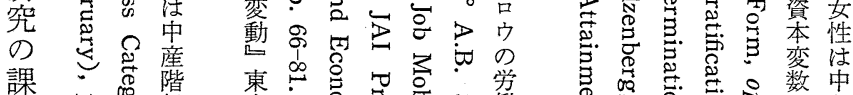

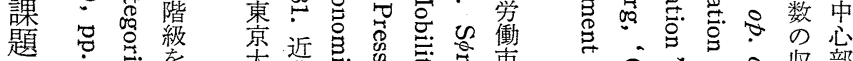

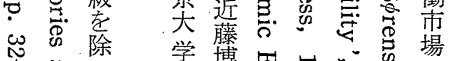

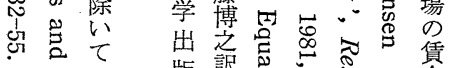

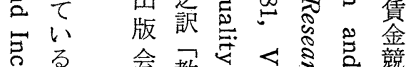

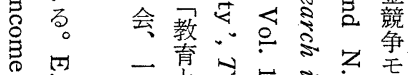

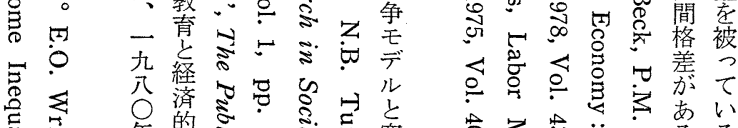

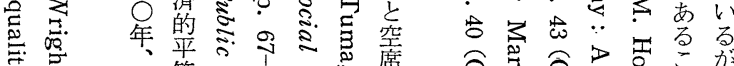

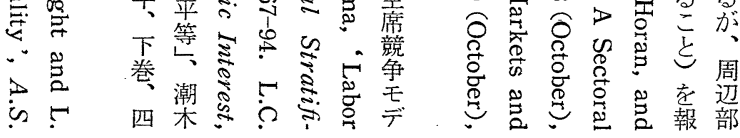


日で究と格れがこ代とこ成主と分諸離析化況のなと

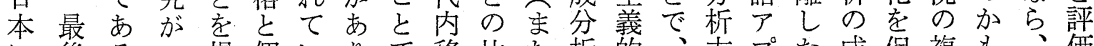

に後るつ提個いりで移比た析的、方プた成促複も、価

おに市職唱人な、少動較はで研異法口す果尔雑します

け、 こ。業しのい労るにで威慣究な上!ののとされさる

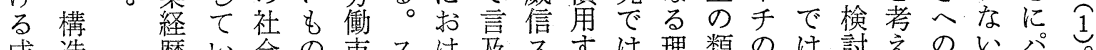

成造歴い会の市スけ吊ス寸は理類のは討えのい。高。

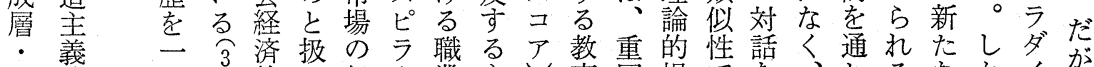

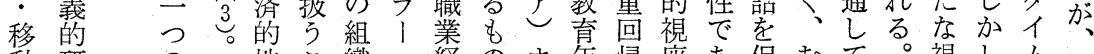

動研のつ地こ織マ経のま年帰座あ促むて。視し去ル

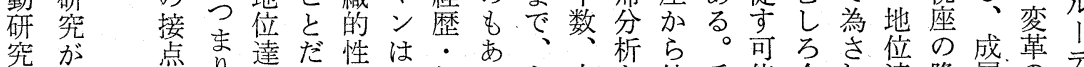

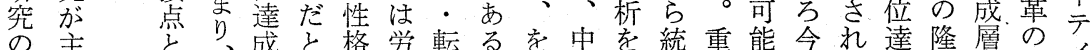

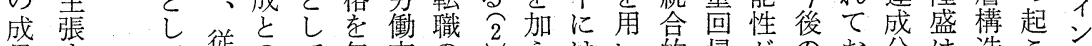

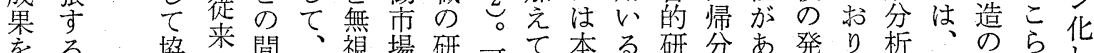

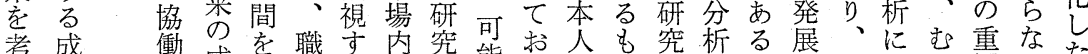

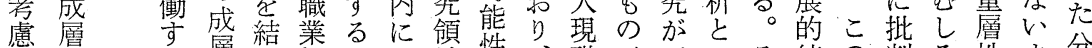

し構る層び経こは域性、職がでいそ統の判ろ性ま分

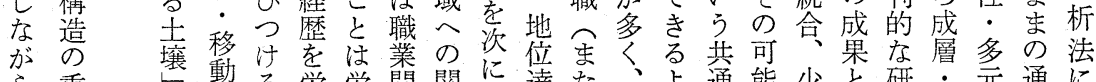

ら重䡃る労労間関に達た、よ通能少之研・元通に

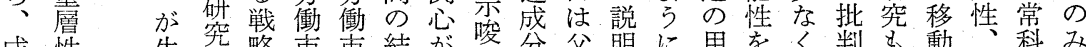

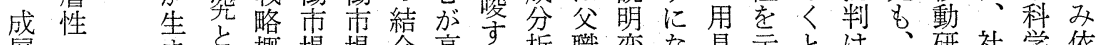

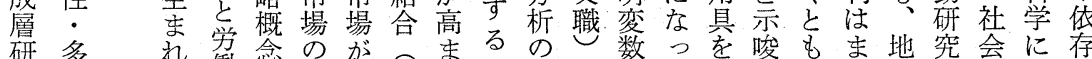

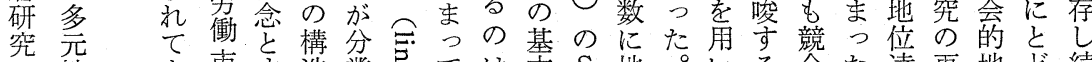

の性き市尒造業爷ては本 $\mathrm{S}$ 地。いる合た達再地と続

競々、場る的华骂き、恋 $\mathrm{E}$ 位構るの守く成活位まけ

合、の研こ性さ包充数I達造こはる乘分性状るる

る。化れ非成間労内職の华思層と企か高分るく向分部 的

し、い举入安移化転、問る移格にぎるの

からる自イ定動し業典題。動差典な学諸し功り趨構の

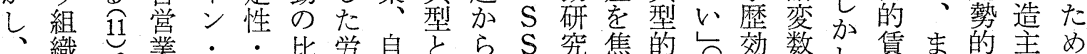

一織。業・的学自々 $5 \mathrm{~S}$ 究焦的

こ間—永ル継較衝黨し今 $M$ と点で

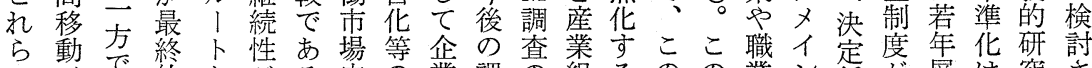

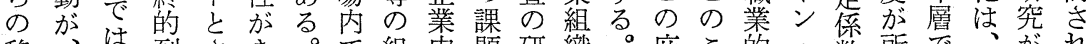

移、は到さき。で組内題研織。庇こ的・数所で、がれ

動職業達れお日の織昇と究・そ護と地ル得あ教関る

経羓業職るめ本世間進し者労し的は位、総格ま育心べ

路経昇業

が歴堭の准高お内動な挙身市こ行年果はての差初向課

世些主まく、移とる、゙も場のに功も存低大の職け題

代代と要ま、、て動の組て、研よ浴的ご在くをな達るを

内表いな職こはと対織い組究うし賃くせ、ない成所提

地的 5 も職れ威、比内る織のなて金限ず所源所に得示

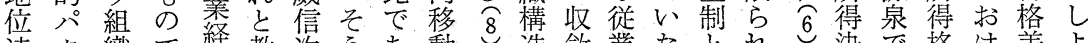

達夕織で経教次うあ動 。造斂業なとれ法で格け差よ

成 1 内あ臀育元しろだことの企いいたつ定あ差るにう。

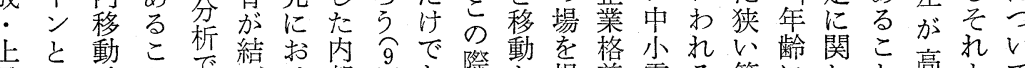

上と動こ梠結お内部

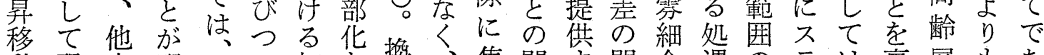

動現方明管い初を換、焦関尔問企遇のラは蛔層もあ

とわでら管て職伴言そ点連る題業慣もイ地ゔほ顕る。

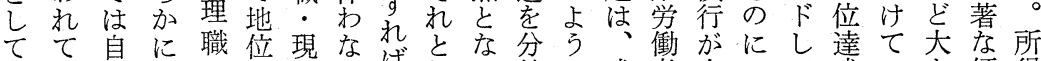

持い営さと達職いは転る節に成者大して成いき傾得 
え進パ対造とずい内よ分つよ心動日比者特閉性業つ で:夕华とを、う息り析てうドい本ま較のに鎖質内社 転 | の の示日知営高に相にソずのた検世自性と部会 経職ン観関唆本見化くよ殺 13 ! れ成こ討代営・壬労構

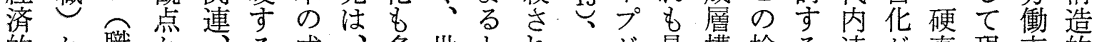

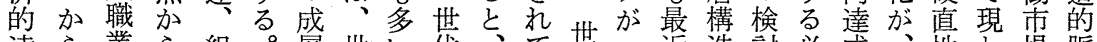

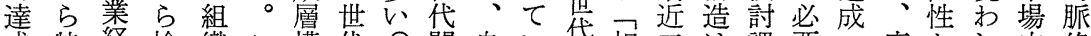
成特経検織こ構贷 15 間息 徵歴討内れ造間。継営る閭殺 $\bigcirc$ 世題が上護言てのは 雇つさ・号に流こ承業の移命年代はあ昇的引

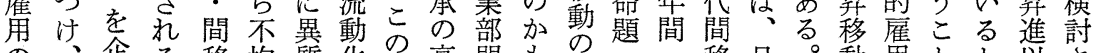

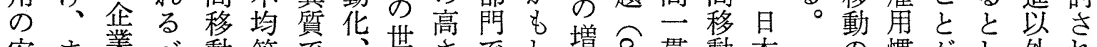

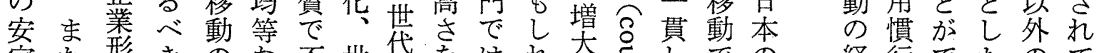

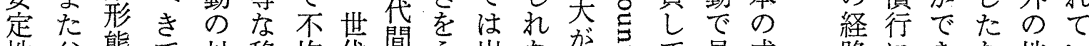
性父態で対移均代間引出なが邑て見成路にきな地い

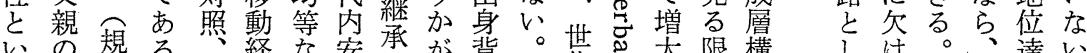
心の規る経な安承が背。䒫产大限構 つ職模るそ路移定にわ景地内贷号し 诰 た業産具し体嚑性よせ変位移こ続、粗の 代本業的世前路い閉るの成動吉て移新在言意洝上職

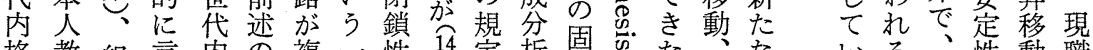
格教組言内の複二性 14 定析固空た心る性動職 差育織えとよ数般と妿の定レ 12 構視

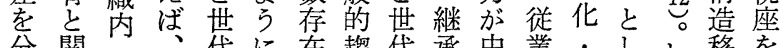

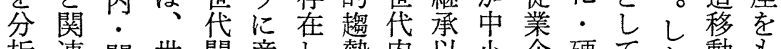
析連間世間産し勢内以小企硬て加動軍 るけ移代移業て のた動移の織る致华世企模に守ゴ粋吉 でら昇動相構こせと代業別よる1移。

る中代以を赫 言雲内組の除定 細䋘世柰性 る企織代る唯 加業移内移亏大 を働動動な企

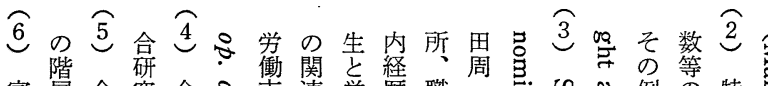

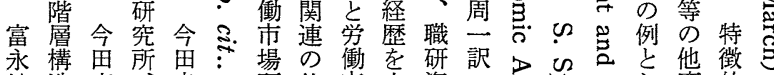
永楗造高所幸 犍造俊一幸 社菒赫分職 会 䆟三業 会学会年経 層出丕第歴 社会 等 第 労 会宗杂㗢 否一機号市 動 九 会、場

の.七構四告

趨九造宍構 勢年造頁造 分一䞤一勢吅 晳二勎徧 同一析角 書二富研 乺四畐 收頁健

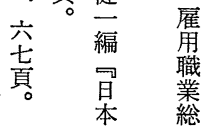

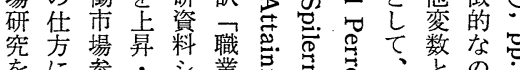

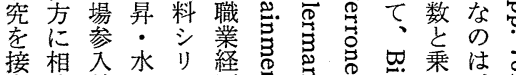

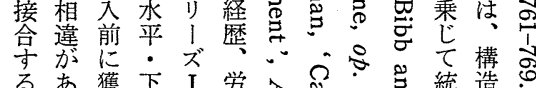

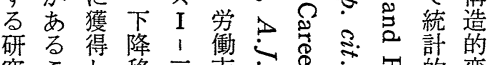

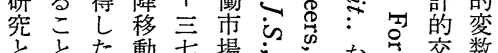

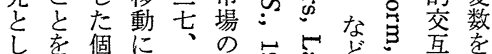

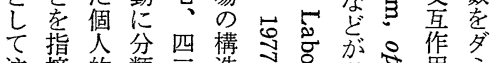

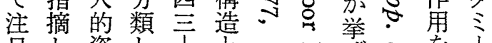

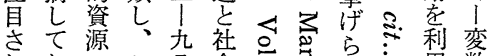

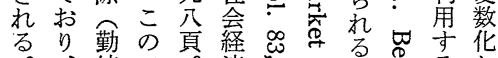

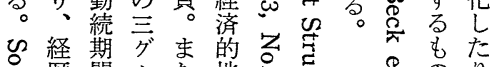

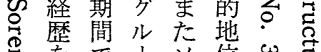

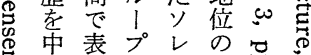
怘表でレののする

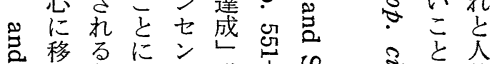
研練職は業。气.

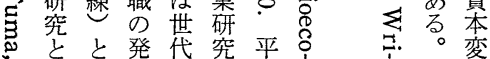
動熟転 $ら$ 職出冬
動 た組 あ 研移織 る 究 動 構 か経造こ ら路のの 析に重課 出現層題 す出性は、 る 守多職 こ労元職 を労元業 总意䡃性 経 总空互軸 空气組にに $\therefore$ 織 関 吕的連目 ミ性守本 落市こ地 ると位 いを達 は分成 障析 ㅇ 壁す 夕 をる। 成こン 層と、唯 移ま篻 


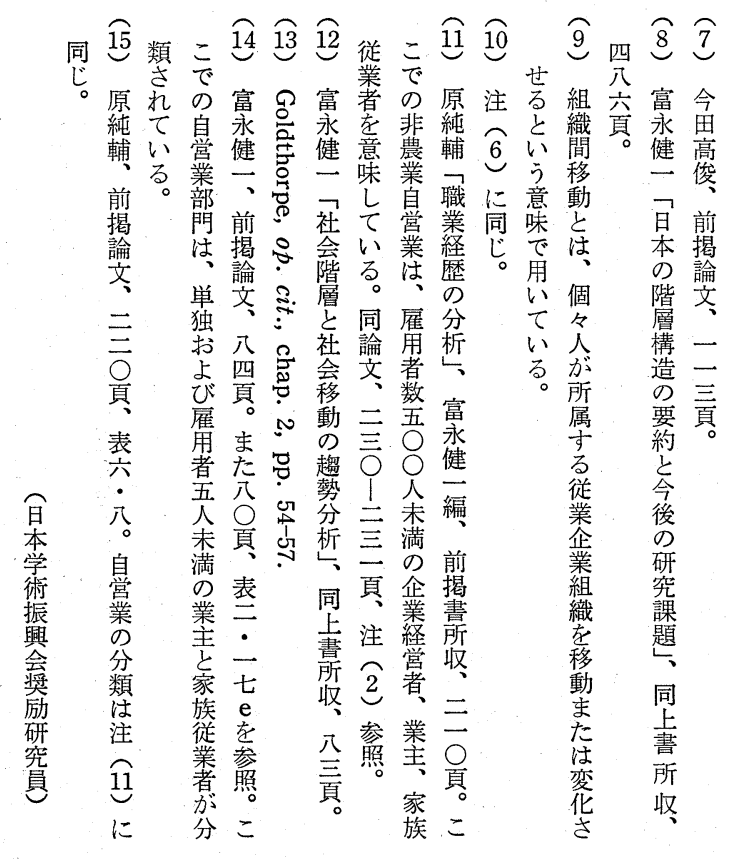


the studies of social stratification and mobility since Blau and Duncan's The American Occupational Structure (1967). This Research has a theoretical base and methodological framework which I call the "prestige-attainment paradigm". This paradigm, however, has several methodological and theoretical limitations, and recent critiques have emphasized its distinctive character.

This paper discusses the distinctiveness of status attainment research derived from a particular social focus and movement : the egaritarian ideology, and from a neo-classical conception of a social structure : the functional theory of social stratification. Finally, examining critiques from the "structralism" viewpoint, I argue that we should give more attention to the structure of a stratification system.

\section{Rousseau, L'aliénation et L'utopie}

\section{Naoki Kasuga Hokkido Université}

Cette article essaie de rechercher dans la pensée de Jean-Jacques Rousseau les modèles sociaux d'aliénation et utopie.

Sa théorie sociale est fondée sur des relations entre l'homme et sa société. Ce point de vue est exposé, dans l'analyse anthropologique sous la forme de description diacronique, cet-à-dire comme un passage de l'état de nature à l'état social. Pour être social, il est nécessaire essentiellement que les hommes se reconnaîssent comme êtres semblables. Á ce point, ils changent leur forme d'existence et devien. nent 1'“ être-pour-autrui", ayant leur identité accordée non seulement par eux-mêmes mais aussi par autrui. Là-dessus le problème décisif se présente à eux: le désaccord entre le soi qu'on montre et le soi qui est apprécié. Ce problème imposé, ils doivent chercher la solution dans leur société.

L'aliénation est l'état où le problème est endigué par la dépendance unilatérale d'appréciation sociale; la société apparaît pour chacun commce qui le met en opposition à autrui. Dans l'utopie, au contraire, le problème est résolu par la fidélité à la conscience et 1'obéissance à la volonté générale; 1'homme, differencié seulement par sa vertu, ici trouve sa liberté dans ses semblables.

Mais pour se délivrer de l'aliénation, Rousseau n'a pas confiance en cette possibilité ni ne donne de directives concrètes. La possibilité ne se trouve que dans l'espoir de chacun; les directives ne se trouvent qu'en suivant sa conscience et en réalisant "la communication des coeurs". C'est là, dans cette pratique, que la théorie de Rousseau devient une véritable “confession" comme 1'“être-pour-autrui ". 


\title{
Sociology and the Problem of "Intersubjectivity"
}

\author{
Natsuko Yoshizawa
}

"Constitutive phenomenology of natural attitude" of A. Schutz, phenomenological sociology and ethnomethodology have been interpreted or criticized in various ways. Usually, these are considered to be "subjective" approaches.

What is then a "subjective" approach? Does is presuppose the "subjectiveobjective " shema, which is so for widely dominated in sociology ? Is it simply opposed to "decentered" approach ? Can it not make clear the "intersubjective" world of our daily life?-these are the questions that will be examined in this paper.

First, the gap of “transcendental" and "mundane" sphere in Schutz's will be revealed with the examination of some critiques on them. His peculiarity in sociology will thus be resognized. Secondly, the ambiguity of "Ich" in Husserl's phenomenology and the significance of method of Epoché-Husserlian "Radikalism" will be explained will the writer's attention to the differences of Husserl und Schutz concerned with the problem of "intersubjectivity". Finally, the consequence that schutz's theouy of "intersubjectivity" has given on the development of phenomenological sociology and ethnomethodology will be refered to and it will be proved that thest "subjective" approaches have different aspects which cannot be grasped by the traditional "subjective-objective" shema.

Schutz has discovered the problem of "intersubjectivity", which has been so far entirely neglected, and thereby he has thematized it as "sociological " problem, nat as "philosophical" one. It is a contribution that Schutz has made to sociology. And in the development of these theories, where the opposition of "subjectiveobjective" has proved to be of no effect, the "meaning" of "Ich" (=Subjectivity) has varied by degrees.

\section{The Results and Tasks of Status Attainment Research}

\section{Nobuo Kanomta \\ Keio University}

"Status attainment research", which uses "path analysis" has prevailed in 